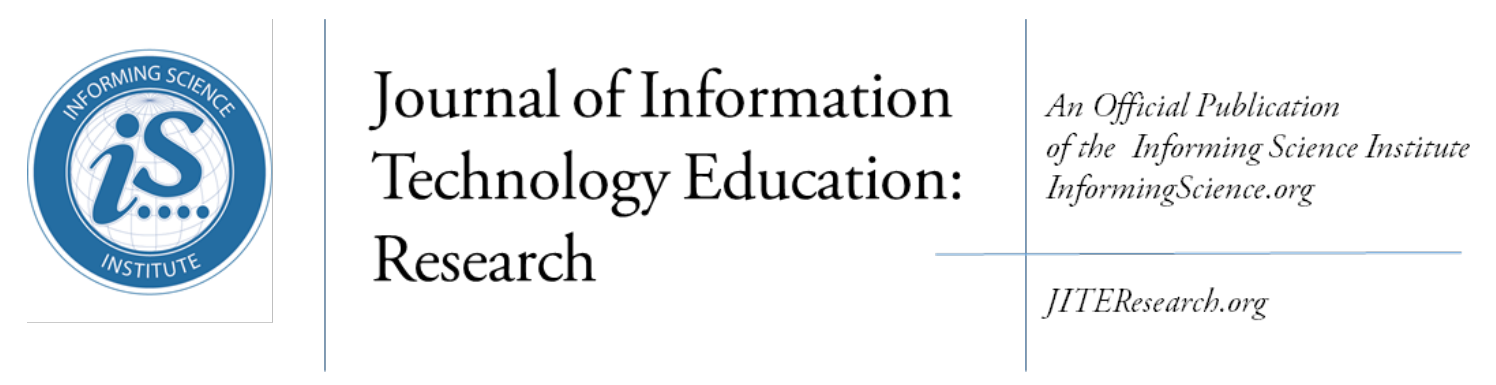

Volume 17, 2018

\title{
DETERMINANTS OF THE ADOPTION OF MOBILE LEARNING SYSTEMS AMONG UNIVERSITY STUDENTS IN INDONESIA
}

Assumption University, Bangkok, $\quad$ epramana@ststs.edu
Thailand

\begin{abstract}
Aim/Purpose This study investigates the factors that influence university students' intentions to adopt mobile learning for their learning activities. A theoretical model is developed based on prior research incorporating constructs from the Unified Theory of Acceptance and Use of Technology (UTAUT), the Technology Acceptance Model (TAM), and specific mobile learning constructs, as well as the moderating effects of gender and experience.
\end{abstract}

Background Mobile Learning, the use of smartphones and other mobile devices in accessing education materials, has become increasingly popular in the last decade. Despite the widespread use of smartphones by students, not many universities have adopted mobile learning in their teaching and learning activities.

Methodology A paper-based questionnaire was used to collect data. A final sample of 696 student responses from five urban universities in Indonesia was used. All of the constructs in the model are measured using existing scales. Structural Equation Modeling (SEM) was used to analyze and develop the theoretical model using Amos software.

Contribution This research contributes to the theoretical understanding of mobile learning adoption as well as practice and provides guidance for university managers to successfully implement mobile learning in their universities. In particular, the study explores moderating effects due to gender and mobile learning experience and presents more complete findings based on total effects instead of only considering direct effects.

Findings Perceived Enjoyment and Perceived Usefulness are the two most influencing factors in the adoption of mobile learning. Gender moderates the direct effect of learning autonomy on behavioral intention. New findings include significant correlations and causal effects involving learning autonomy, perceived enjoy-

Accepted by Editor Zlatko J. Kovacic |Received: February 7, 2018| Revised: April 25, 2018 | Accepted: September 19, 2018.

Cite as: Pramana, E. (2018). Determinants of the adoption of mobile learning systems among university students in Indonesia. Journal of Information Tecbnology Education: Research, 17, 365-398. https://doi.org/10.28945/4119

(CC BY-NC 4.0) This article is licensed to you under a Creative Commons Attribution-NonCommercial 4.0 International License. When you copy and redistribute this paper in full or in part, you need to provide proper attribution to it to ensure that others can later locate this work (and to ensure that others do not accuse you of plagiarism). You may (and we encourage you to) adapt, remix, transform, and build upon the material for any non-commercial purposes. This license does not permit you to use this material for commercial purposes. 
ment, facilitating condition, perceived mobility, social influence, perceived usefulness, and perceived ease of use.

Recommendations University managers should ensure that the students can enjoy mobile learning for Practitioners and also find it useful for their learning activities. Furthermore, the University has to facilitate and support the mobile learning system and infrastructure, and they also need to create a university learning environment where professors, senior students, and friends all encourage the adoption of mobile learning.

Recommendations Research on mobile learning adoption should consider the moderator effects on for Researchers the factors of behavioral intention to adopt mobile learning. Different groupings within these moderators should also be examined.

Future Research Additional studies may address and compare findings with respondents from rural Indonesian universities where the infrastructure and facilities are inferior to those in urban universities as well as participants from other cultural contexts.

Keywords mobile learning, university, factors, moderating effect, UTAUT, TAM, SEM

\section{INTRODUCTION}

The use of smartphones and other mobile devices in accessing learning materials has become increasingly popular in the last decade. This leads to the new terminology mobile-learning (m-learning). It is a new paradigm in education where knowledge can be transferred via mobile devices such as smartphones, computer tablets, and laptops. The idea of mobile learning is interesting because it integrates mobility into the already famous context of electronic learning (e-learning). In its infancy, mobile learning is acknowledged as electronic learning made mobile. Both mobile learning and electronic learning are derived from distance learning, where mobile learning complements electronic learning with the advantage of learning anywhere and at any time (Ozuorcun \& Tabak, 2012). Learners may access educational materials directly from their mobile devices, beyond the boundaries of traditional classrooms and formal study time. Mobile learning answers the growing need for communication and collaboration with the ability to obtain relevant information at the appropriate time. It offers opportunities to enhance existing traditional educational systems by following the trends of mobility, communication, and collaboration among learners.

Despite the widespread use of smartphones by students, not many universities have adopted mobile learning in their teaching and learning activities. Mobile devices are mostly used only for learning material distribution and administration purposes but not as tools for learning. There is a need for research to study the factors for the acceptance of mobile learning in higher-education institutions as a complement to current teaching and learning activities. Mobile learning is supposed to complement and enhance current e-learning or traditional learning classes, not to replace them (Motiwalla, 2007). One of the most important advantages of mobile learning is that students may study at their own pace and in their own place.

This study addresses four specific and related research questions: (a) What are the factors that are related to the behavioral intention of users to adopt mobile learning systems? (b) What are the relationships among the factors in question (a)? (c) Which factors have a significant causal or moderator effect on the behavioral intention to adopt mobile learning systems? and (d) What are the theoretical and practical implications of the answer to question (c)? The outcomes of the study are expected to contribute to the theoretical understanding of mobile learning adoption for university students and to provide guidelines for university managers who are interested in adopting mobile learning in their educational institutions. 
Most of mobile learning studies that can be found from the existing literature are based on the Technology Acceptance Model (TAM) and the Unified Theory of Acceptance and Use of Technology (UTAUT). Both TAM and UTAUT models may not fully address the unique features of mobile learning systems. This empirical study employs constructs from both TAM and UTAUT (perceived usefulness, perceived ease of use, social influence, facilitating conditions), as well as additional constructs from other adoption theories or specific previous studies of mobile learning such as perceived mobility, learning autonomy, perceived innovativeness, perceived enjoyment, and self-efficacy. Furthermore, Venkatesh, Morris, Davis, and Davis (2003) suggested the use of moderating factors (age, gender, experience, voluntariness of use) in their popular UTAUT model. However, many of the previous studies of mobile learning adoption based on UTAUT do not consider those moderating factors in their proposed models. This study explores gender and mobile learning experience as moderating factors that may affect the direct effects of the determinants of the behavioral intention of users to adopting mobile learning for their studies. The other two moderating factors, age and voluntariness of use, are not included in this study because the participants of the study are all bachelor students and therefore within a narrow range of ages, and the nature of mobile learning adoption for their study is voluntary for all the students.

The subsequent section presents the literature review that encompasses prior studies on the adoption of mobile learning and the model variables, followed by the theoretical model and research hypotheses of this study. Then, the results of the data analysis, model analysis and development, full analysis of the final model, and hypotheses testing are presented. The last section of this study discusses the findings, practical implications of the findings, limitations of the study, and possible future related studies.

\section{LITERATURE REVIEW}

The term e-learning was first coined by Jay Cross in 1999 (Cross, 2004). Rosenberg (2001) suggests that e-learning involves the utilization of internet technology to deliver learning opportunities. Cross (2004) also suggests that e-learning is learning on internet time, the convergence of learning and networks. However, Khan (2005) suggests a broader definition of e-learning by defining it as "an innovative approach for delivering a well-designed, learner-centered, interactive, and facilitated learning environment to anyone, anyplace, anytime, by utilizing the attributes and resources of various digital technologies along with other forms of learning materials suited for open, flexible, and distributed learning environment." Khan (2005) argues that e-learning is more about learning in collaborative manner where the students may share and cooperate during their learning process, rather than merely the use of internet technology as the delivery system as previously suggested by Cross (2004) and Rosenberg (2001). E-Learning has been implemented and utilized by many higher-education institutions to facilitate teaching and learning. E-Learning is basically a web-based system that makes learning materials available to learners regardless time restrictions or physical location as long as the learner has access to any internet-enabled devices such as desktop computers or laptops. The invention of portable devices such as smartphones and tablets eliminates the limitation of learning location and leads to the emergence of mobile learning. With those portable devices, learners can conveniently access learning content from virtually anywhere, as long as they have internet connection.

There are different definitions of mobile learning, depending on its content from various points of view such as the mobility of the learners, its relationship with electronic learning, or mobile device applications. Wang, Wu, and Wang (2009) define mobile learning as the delivery of learning to students anytime and anywhere through the use of wireless Internet and mobile devices, including mobile phones, personal digital assistants (PDAs), smartphones, and digital audio players. Kwon and Lee (2010) define mobile learning as an educational environment where students can do their learning activities using mobile devices over a wireless network anywhere, anytime. In other words, a learner has a freedom of the time and place for learning, with the aid of mobile devices and the internet. Kukulska-Hulme (2009) suggests that there is no agreed definition of mobile learning due to the rap- 
id development of the field and also the ambiguity of the term "mobile". It may relate to mobile technology or the learner's mobility. Both aspects are equally important. With mobile learning, learners could engage in learning activities without being limited to a fixed, particular location, with the aid of mobile technologies. In this study, mobile learning is defined as an educational environment where students can do their learning activities using any internet-enabled mobile devices over a wireless network anywhere, anytime. This definition is adapted from Kwon and Lee (2010) and Wang et al. (2009). The aforementioned learning activities may include reading, listening, watching videos related to the students' learning interests, answering questions in quizzes, or even participating in a discussion forum with their peers and teachers. The mobile devices used in this mobile learning may include, but are not limited to smartphones, tablets, personal digital assistants, notebooks, netbooks, and laptops.

\section{PRIOR STUDIES ON THE ADOPTION OF MOBILE LEARNING}

Research on the adoption of mobile learning has been carried out based on many different popular technology adoption theories such as the Technology Acceptance Model, the Unified Theory of Acceptance and Use of Technology, and the Theory of Planned Behavior. Table 1 describes prior studies from 2007 to 2017 in mobile learning adoption.

Table 1: Prior studies in the adoption of mobile learning

\begin{tabular}{|c|c|c|}
\hline $\begin{array}{l}\text { Technology } \\
\text { Adoption } \\
\text { Theory }\end{array}$ & Project Focus & References \\
\hline TAM & $\begin{array}{l}\text { Elucidating user behavior of mobile learning } \\
\text { Factors driving the adoption of mobile learning } \\
\text { Students' willingness to use mobile learning } \\
\text { Exploring Gender Differences on General and Specific Com- } \\
\text { puter Self-Efficacy in mobile learning adoption } \\
\text { Determinants of mobile learning adoption, Personal Innova- } \\
\text { tiveness in IT } \\
\text { Factors influencing mobile learning adoption intention in high- } \\
\text { education } \\
\text { Mobile learning adoption for teachers }\end{array}$ & $\begin{array}{l}\text { Huang et al. (2007) } \\
\text { Liu \& Carlsson (2010) } \\
\text { Park et al. (2012) } \\
\text { Bao et al. (2013) } \\
\text { Tan et al. (2014) } \\
\text { Khanh \& Gim (2014) } \\
\text { Sanchez-Prieto et al. (2017) }\end{array}$ \\
\hline $\begin{array}{l}\text { TAM \& } \\
\text { UTAUT }\end{array}$ & $\begin{array}{l}\text { Factors influencing students' intention to use mobile learning in } \\
\text { Jordan higher-education } \\
\text { Exploring students' awareness and perceptions: Influencing } \\
\text { factors and individual differences driving mobile learning adop- } \\
\text { tion } \\
\text { Mobile learning adoption Framework, Learner's perspective }\end{array}$ & $\begin{array}{l}\text { Althunibat (2015) } \\
\text { Sabah, N.M. (2016) } \\
\text { Rehman et al. (2016) }\end{array}$ \\
\hline UTAUT & $\begin{array}{l}\text { The determinants and age and gender differences in the ac- } \\
\text { ceptance of mobile learning } \\
\text { Mobile learning determinants } \\
\text { Factors influencing students' acceptance of mobile learning in } \\
\text { higher-education } \\
\text { Behavioral Intention to Adopt Mobile Technology among Ter- } \\
\text { tiary Students } \\
\text { Students' behavior intention to adopt and use mobile learning } \\
\text { in higher-education in East Africa } \\
\text { Mobile learning adoption for Engineering Education } \\
\text { Learners' readiness in adopting mobile learning in higher- } \\
\text { education, GCC countries } \\
\text { Determinants of mobile learning adoption in higher-education }\end{array}$ & $\begin{array}{l}\text { Wang et al. (2009) } \\
\text { Lowenthal (2010) } \\
\text { Abu-Al-Aish \& Love (2013) } \\
\text { Jambulingam (2013) } \\
\text { Mtebe \& Raisamo (2014) } \\
\text { Huan et al. (2015) } \\
\text { Shorfuzzaman \& Alhussein } \\
\text { (2016) } \\
\text { Masrek \& Samadi (2017) }\end{array}$ \\
\hline TPB & Mobile learning readiness in higher-education & Cheon et al. (2012) \\
\hline
\end{tabular}


From Table 1 it is seen that the following trends in previous research related to the use of theoretical models are evident.

The Technology Acceptance Model (Davis, 1989) is one of the most popular technology adoption theory used for mobile learning adoption studies. The Technology Acceptance Model (TAM) is developed based on the Theory of Reasoned Action, with the objective of providing an explanation about the determinants of technology acceptance by the end-users. Those TAM-based studies on mobile learning employ the traditional constructs of TAM (Perceived Usefulness and Perceived Ease of Use), additional constructs from other adoption theories (such as Self-Efficacy, Personal Innovativeness, Social Influence, Facilitating Conditions, and Perceived Enjoyment) and a variety of additional constructs specific to mobile learning (such as Perceived Mobility and Learning Autonomy). It is also interesting to note that only a few studies include Attitude as a determinant of behavioral intention to adopt mobile learning (Khanh \& Gim, 2014; Park et al., 2012). Despite some minor difference in the outcome of those studies, almost all results showed that Perceived Usefulness and Perceived Ease of Use are significant determinants of behavioral intention to adopt mobile learning. Similar positive results also applied for other determinants of behavioral intention to adopt mobile learning such as Perceived Innovativeness (Liu et al., 2010), Social Influence (Park et al., 2012), Perceived Enjoyment (Huang et al., 2007) and Perceived Mobility (Rehman et al., 2016). Investigation into the dependencies among constructs showed that Perceived Ease of Use, Self-Efficacy, Personal Innovativeness, Facilitating Conditions, and Social Influence are significant determinants of Perceived Usefulness. Furthermore, Perceived Ease of Use is influenced by Self-Efficacy, Personal Innovativeness and Facilitating Conditions.

The Unified Theory of Acceptance and Use of Technology (UTAUT) is proposed by Venkatesh et al. (2003) as a unification of some popular technology adoption theories such as the Theory of Reasoned Action (TRA), Technology Acceptance Model (TAM), Theory of Planned Behavior (TPB), Innovation Diffusion Theory (IDT), Motivational Model (MM), Model of PC Utilization (MPCU), Social Cognitive Theory (SCT), and Combined-TAM-TPB (C-TAM-TBP). There are four key determinants used in UTAUT. The first three constructs (Performance Expectancy, Effort Expectancy, and Social Influence) determine the Behavioral Intention, and the last one (Facilitating Conditions) determines Use Behavior. UTAUT also features four moderating factors: Gender, Age, Experience, and Voluntariness of Use. It is interesting to note that only a few of those UTAUT-based studies have included the moderating factors into their proposed model. Wang et al. (2009) found a partial support for the moderating factor of Age on the direct effect of Effort Expectancy and Social Influence on the Behavioral Intention to adopt mobile learning. They also found that the moderating factor of Gender on the direct effect of Social Influence on the Behavioral Intention is significant for men, but insignificant for women. Furthermore, Learning Autonomy is a stronger determinant of behavioral intention for women than for men. Abu-Al-Aish \& Love (2013) found that students' experience with mobile devices moderates the effects of Effort Expectancy, Social Influence, and Personal Innovativeness on Behavioral Intention to adopt mobile learning. On the contrary, Jambulingam (2013) and Lowenthal (2010) could not find any support on the moderating factors of Age and Gender in influencing the determinants of Behavioral Intention to adopt mobile learning. The four original constructs of UTAUT (Performance Expectancy, Effort Expectancy, Social Influence, and Facilitating Conditions) are shown to be significant determinants of the behavioral intention to adopt mobile learning in most of those aforementioned studies. Additional constructs such as Perceived Enjoyment (Huan et al., 2015), Personal Innovativeness (Abu-Al-Aish \& Love, 2013), Learning Autonomy (Huan et al., 2015; Lowenthal, 2010; Masrek \& Samadi, 2017; Wang et al., 2009), and Perceived Mobility (Shorfuzzaman \& Alhussein, 2016) also are shown to be the influencing determinants of the behavioral intention to adopt mobile learning.

The Theory of Planned Behavior (Ajzen, 1991) suggests that the individual behavior is determined by behavior intention. Behavior intention itself is driven by three constructs: attitude, subjective norm, and perceived behavioral control. Attitude is the individual's positive or negative feelings about 
performing a behavior. Subjective norm is the individual's perception that people important to the individual should perform the behavior. Perceived behavior control is the individual's perception of the level of difficulty in performing a behavior. Cheon et al. (2012) found that students' attitudes, subjective norm, and behavioral control influenced their intention to adopt mobile learning. Perceived behavioral control is the most significant determinant of the intention to adopt mobile learning, followed by attitude and subjective norm. They also found that instructors may significantly influence college students' intention to adopt mobile learning, but not the students' peers.

Careful investigation into the constructs used in the theoretical models from those prior studies showed that there are five constructs commonly used as specific constructs in mobile learning adoption in addition to the original TAM/UTAUT/TPB constructs. They are Learning Autonomy, Perceived Mobility, Perceived Enjoyment, Self-Efficacy, and Personal Innovativeness. However, most studies incorporate at most three of them in their theoretical models. Furthermore, most prior studies did not include moderating factors which are an important feature of UTAUT-based studies. In addition, the analyses of the models in previous studies have been concerned with only direct causal effects with no analyses of indirect effects and total effects. This approach results in an incomplete understanding of the influences among variables in the model. The analyses and development of the theoretical model in this study aims to address these deficiencies and consequently enhance the comprehensiveness of the findings.

\section{THE DEFINITION OF MODEL VARIABLES}

Table 2 presents operational definitions for the model variables and the symbols used to represent them. References identify previous studies from which the operational definitions were derived.

Table 2: Operational definitions for model variables

\begin{tabular}{|c|c|c|}
\hline Variable (Symbol) & Definition & Reference \\
\hline $\begin{array}{l}\text { Perceived Mobility } \\
\text { (PM) }\end{array}$ & $\begin{array}{l}\text { The extent to which an individual values the mobility provided by } \\
\text { mobile devices in order to access and check information any- } \\
\text { where and at any time. }\end{array}$ & $\begin{array}{l}\text { Khanh \& Gim } \\
(2014)\end{array}$ \\
\hline $\begin{array}{l}\text { Social Influence } \\
\text { (SI) }\end{array}$ & $\begin{array}{l}\text { The degree to which an individual perceives that important per- } \\
\text { sons believe he or she should use a mobile learning system. }\end{array}$ & $\begin{array}{l}\text { Venkatesh et al. } \\
(2003)\end{array}$ \\
\hline $\begin{array}{l}\text { Self-Efficacy } \\
\text { (SE) }\end{array}$ & $\begin{array}{l}\text { People's judgments of their capabilities and skills to use m- } \\
\text { learning systems. }\end{array}$ & Bandura (1986) \\
\hline $\begin{array}{l}\text { Personal Innovative- } \\
\text { ness (PI) }\end{array}$ & An individual's willingness to try out new technologies. & $\begin{array}{l}\text { Agarwal \& Prasad } \\
(1998)\end{array}$ \\
\hline $\begin{array}{l}\text { Facilitating Condition } \\
\text { (FC) }\end{array}$ & $\begin{array}{l}\text { The degree to which an individual believes that organizational } \\
\text { and technical infrastructure exists to support the use of a mobile } \\
\text { learning system. }\end{array}$ & $\begin{array}{l}\text { Venkatesh et al. } \\
(2003)\end{array}$ \\
\hline $\begin{array}{l}\text { Learning Autonomy } \\
\text { (LA) }\end{array}$ & $\begin{array}{l}\text { The extent to which an individual acts responsibly and has con- } \\
\text { trol over the process of learning with mobile devices. }\end{array}$ & $\begin{array}{l}\text { Cheon et al. } \\
(2012)\end{array}$ \\
\hline $\begin{array}{l}\text { Perceived Enjoyment } \\
\text { (PE) }\end{array}$ & $\begin{array}{l}\text { The extent to which mobile learning is perceived by an individual } \\
\text { to be enjoyable in its own right, apart from any performance } \\
\text { consequences that may be anticipated. }\end{array}$ & Davis et al. (1992) \\
\hline $\begin{array}{l}\text { Perceived Usefulness } \\
\text { (PU) }\end{array}$ & $\begin{array}{l}\text { The degree to which a person believes that using a mobile } \\
\text { learning system enhances their learning performance. }\end{array}$ & Davis (1989) \\
\hline $\begin{array}{l}\text { Perceived Ease of Use } \\
\text { (PEU) }\end{array}$ & $\begin{array}{l}\text { The degree to which a person believes that using a mobile } \\
\text { learning system is free of effort. }\end{array}$ & Davis (1989) \\
\hline $\begin{array}{l}\text { Behavioral Intention } \\
\text { (BI) }\end{array}$ & $\begin{array}{l}\text { A measure of the strength of an individual's intention to use mo- } \\
\text { bile learning in the future assuming that it is available to them. }\end{array}$ & Ajzen (1991) \\
\hline Gender & An individual's gender classified as male or female. & - \\
\hline $\begin{array}{l}\text { Mobile Learning Expe- } \\
\text { rience }\end{array}$ & Months of experience in using a mobile learning system. & - \\
\hline
\end{tabular}

The following are additional comments related to the definitions in Table 2. 


\section{Perceived Mobility}

Mobility is considered as the main element for mobile learning that enables learning activity to take place anywhere and also at any time with the utilization of internet-enabled mobile devices. Prior studies showed that Perceived Mobility has positive influence on Perceived Usefulness and also on behavioral intention to adopt mobile learning. In this study, Perceived Mobility is expected to be a significant determinant of Perceived Usefulness and Behavioral Intention to adopt mobile learning.

\section{Social Influence}

Social Influence is also known as Subjective Norm in the Theory of Reasoned Action and Theory of Planned Behavior, or Image in the Innovation Diffusion Theory. Prior researches suggest that social influence is a significant factor in influencing an individual to adopt a new technology (Moore \& Benbasat, 1991). In the context of mobile learning, the effect of Social Influence on the behavioral intention to adopt mobile learning has been explored with positive results. Social Influence has also been shown to have effect on Perceived Usefulness. Therefore, Social Influence is expected to be a significant determinant of Perceived Usefulness and Behavioral Intention to adopt mobile learning.

\section{Self-Efficacy}

Self-Efficacy is first introduced by Bandura in his social cognitive theory (Bandura, 1977). It refers to the individual's beliefs about one's ability and motivation to perform specific tasks. It also plays an important role in shaping individual's feelings and behaviors. Later on, this definition has been adapted to suit technology adoption models and defined as the assessment of one's own ability to use an information system (Compeau \& Higgins, 1995). In the context of mobile learning, it indicates an individual's perception of his/her capability to use a mobile device to engage in learning tasks, locate and manipulate information, communicate, and collaborate using social technologies (Huan et al., 2015). The influence of self-efficacy on the adoption of mobile learning in education has been explored with positive result. Self-Efficacy has also been shown to have influence on Perceived Usefulness and Perceived Ease of Use. Therefore, this study incorporates Self-Efficacy to the research model in order to explore the relationships between Self-Efficacy and Perceived Usefulness, Self-Efficacy and Perceived Ease of Use, Self-Efficacy and Behavioral Intention to adopt mobile learning.

\section{Personal Innovativeness}

Adapted from the Innovation Diffusion Theory, Personal Innovativeness suggests that users with higher level of innovativeness are more likely to adopt a new technology innovation compared with those with lower level of innovativeness. In the context of mobile learning, it is expected that students with higher personal innovativeness have a more positive intention to adopt mobile learning in their study. Prior studies in the effect of Personal Innovativeness on behavioral intention to adopt mobile learning have shown positive results. Furthermore, Personal Innovativeness also has influence on Perceived Usefulness and Perceived Ease of Use. It is expected that students with high Personal Innovativeness would be more risk taking and have a more positive intention to adopt mobile learning in their studies. Therefore, this study incorporates Personal Innovativeness to the research model in order to explore the relationships between Personal Innovativeness and Perceived Usefulness, Personal Innovativeness and Perceived Ease of Use, Personal Innovativeness and Behavioral Intention to adopt mobile learning.

\section{Facilitating Conditions}

Facilitating conditions include aspects of the technological and/or organizational environment that are designed to remove barriers to use. In the context of mobile learning, the facilitating conditions refer to resources, knowledge, internet speed, and support personnel. The students' decision in adopting mobile learning is believed to be influenced by their perception on the availability of those 
resources to deliver mobile learning. Furthermore, Facilitating Conditions also has influence on Perceived Usefulness and Perceived Ease of Use. This study incorporates Facilitating Conditions to the research model in order to explore the relationships between Facilitating Conditions and Perceived Usefulness, Facilitating Conditions and Perceived Ease of Use, Facilitating Conditions and Behavioral Intention to adopt mobile learning.

\section{Learning Autonomy}

Learning autonomy allows students to set their own learning objectives and fully in charge of their progress. Prior studies in mobile learning have shown that Learning Autonomy significantly influences the acceptance of mobile learning. This study incorporates Learning Autonomy to the theoretical model in order to explore its relationship with Behavioral Intention to adopt mobile learning.

\section{Perceived Enjoyment}

Perceived Enjoyment allows individuals to enjoy learning activity with their mobile devices. It is an example of intrinsic motivation and it has been known to influence user acceptance on new technology. Prior studies showed that Perceived Enjoyment is an influencing determinant of Perceived Ease of Use and also Behavioral Intention to adopt mobile learning. This study incorporates Perceived Enjoyment to the research model in order to explore its relationship with Perceived Ease of Use and the Behavioral Intention to adopt mobile learning.

\section{Perceived Usefulness}

Venkatesh et al. (2003) suggest that Perceived Usefulness has similarities with Performance Expectancy (Unified Theory of Acceptance and Use of Technology), Relative Advantages (Innovation Diffusion Theory) and Outcome Expectations (Social Cognitive Theory). Perceived Usefulness in mobile learning means that learners will find mobile learning useful because they can do learning activities more quickly, flexibly and effectively (Wang et al., 2009). There have been many studies in mobile learning where Perceived Usefulness in TAM-based studies or Performance Expectancy in UTAUTbased studies is known to be the determinant of Behavioral Intention to adopt mobile learning. The above research works in mobile learning showed that individuals will accept mobile learning if they find it useful. Therefore, it is expected that Perceived Usefulness will be a strong factor for learners to adopt mobile learning.

\section{Perceived Ease of Use}

Venkatesh et al. (2003) suggest that Perceived Ease of Use has similarities with Effort Expectancy (Unified Theory of Acceptance and Use of Technology) and Complexity (Innovation Diffusion Theory, with negative correlation). There have been many studies in mobile learning where Perceived Ease of Use in TAM-based studies or Effort Expectancy in UTAUT-based studies is known to be the determinant of Behavioral Intention to adopt mobile learning. Perceived Ease of Use is also known as the determinant of Perceived Usefulness. Therefore, it is expected that Perceived Ease of Use will be a determinant for Perceived Usefulness as well as for the learners' Behavioral Intention to adopt mobile learning.

\section{Behavioral Intention}

Behavioral Intention is regarded as the main factor for users' acceptance in use behavior (Venkatesh et al., 2003). In the context of mobile learning, it measures the individual's commitment toward utilizing mobile learning providing it is available to them as a free choice in the future. This study measures Behavioral Intention instead of the actual use due to the actual condition of the organization where the study is conducted in which the mobile learning implementation is still at early stage and in some cases individuals are compelled to use mobile learning. 


\section{Moderating Factors - Gender and Mobile Learning Experience}

People are classified as male or female, the only two possible values for gender. Despite the fact that UTAUT is very popular and commonly used in technology adoption studies, there are only a few studies in mobile learning that consider gender as the moderating factor of the determinants of the behavioral intention. One of them is a study performed by Wang et al. (2009), where they came up with a result that the Self-Management of Learning construct appears to be a stronger predictor for female than male in the adoption of mobile learning. They also found that the Social Influence construct appears to be a stronger predictor for male than female in the adoption of mobile learning. Bao et al. (2013) also investigated gender differences and came up with a result that Perceived Usefulness construct appears to be a stronger predictor for male than female in the adoption of mobile learning.

Mobile learning experience is the number of months of experience an individual has been using mobile learning system for their educational activities. Abu-Al-Aish and Love (2013) investigate the users' acceptance of mobile learning based on UTAUT, and they use mobile device experience as the moderating factor that influences the determinants on behavioral intention in adopting mobile learning. They divide the respondents into two groups: group one with three years or less experience and group two with more than three years' experience. Results showed that effort expectancy, social influence, and personal innovativeness are stronger predictors of mobile learning adoption for students with three years or less experience. Those results are in agreement with Venkatesh et al. (2003) who also found that effort expectancy and social influence will affect the behavioral intention for IT usage at an early stage of experience.

\section{THE MEASUREMENT OF MODEL VARIABLES}

The two moderator variables (gender and mobile learning experience) are measured as described in their operational definitions in Table 2. Gender is a nominal level variable with two values (male and female) while mobile learning experience is measured as an ordinal level variable using categories and it is converted to a ratio scale variable using the mid-point of each category. Table 3 presents the details for the measurement of the other 10 model variables each of which is a latent variable with the number of indicators shown, including their references.

Table 3: Measurement of latent variables

\begin{tabular}{|l|l|l|l|}
\hline Variable (Symbol) & Indicators & $\begin{array}{l}\text { Number of } \\
\text { Indicators }\end{array}$ & Existing Measuring Instrument \\
\hline $\begin{array}{l}\text { Perceived Mobility (PM) } \\
\text { Social Influence (SI) }\end{array}$ & PM1, PM2, PM3, PM4 & 4 & Huang et al. (2007) \\
Self-Efficacy (SE) & SI1, SI2, SI3, SI4 & 4 & Wang et al. (2009) \\
Personal Innovativeness (PI) & SE1, SE2, SE3, SE4 & 4 & Park et al. (2012) \\
Piu et al. (2010) \\
Facilitating Condition (FC) & FC1, FC2, PI3, PI4 & 4 & Mtebe \& Raisamo (2014) \\
Learning Autonomy (LA) & LA1, LA2, LA3, LA4 & 4 & Wang et al. (2009) \\
$\begin{array}{l}\text { Perceived Enjoyment (PE) } \\
\text { Perceived Usefulness (PU) }\end{array}$ & PE1, PE2, PE3, PE4 & 4 & Huang et al. (2007) \\
Perceived Ease of Use (PEU) & PU1, PU2, PU3, PU4 & 4 & Lowenthal (2010) \\
Behavioral Intention (BI) & PEU1, PEU2, PEU3, PEU4 & 4 & Wang et al. (2009) \\
Bang et al. (2009)
\end{tabular}

Each of the indicators is measured using a 5-point Likert scale with the measures treated in data analyses as interval scale measures. The items that are used in section 2 of the study questionnaire to measure each of the indicators are listed in the Appendix.

\section{THEORETICAL MODEL}

The model depicted in Figure 1 is derived from existing theories and previous studies of the adoption of mobile learning which are described in the literature review. 


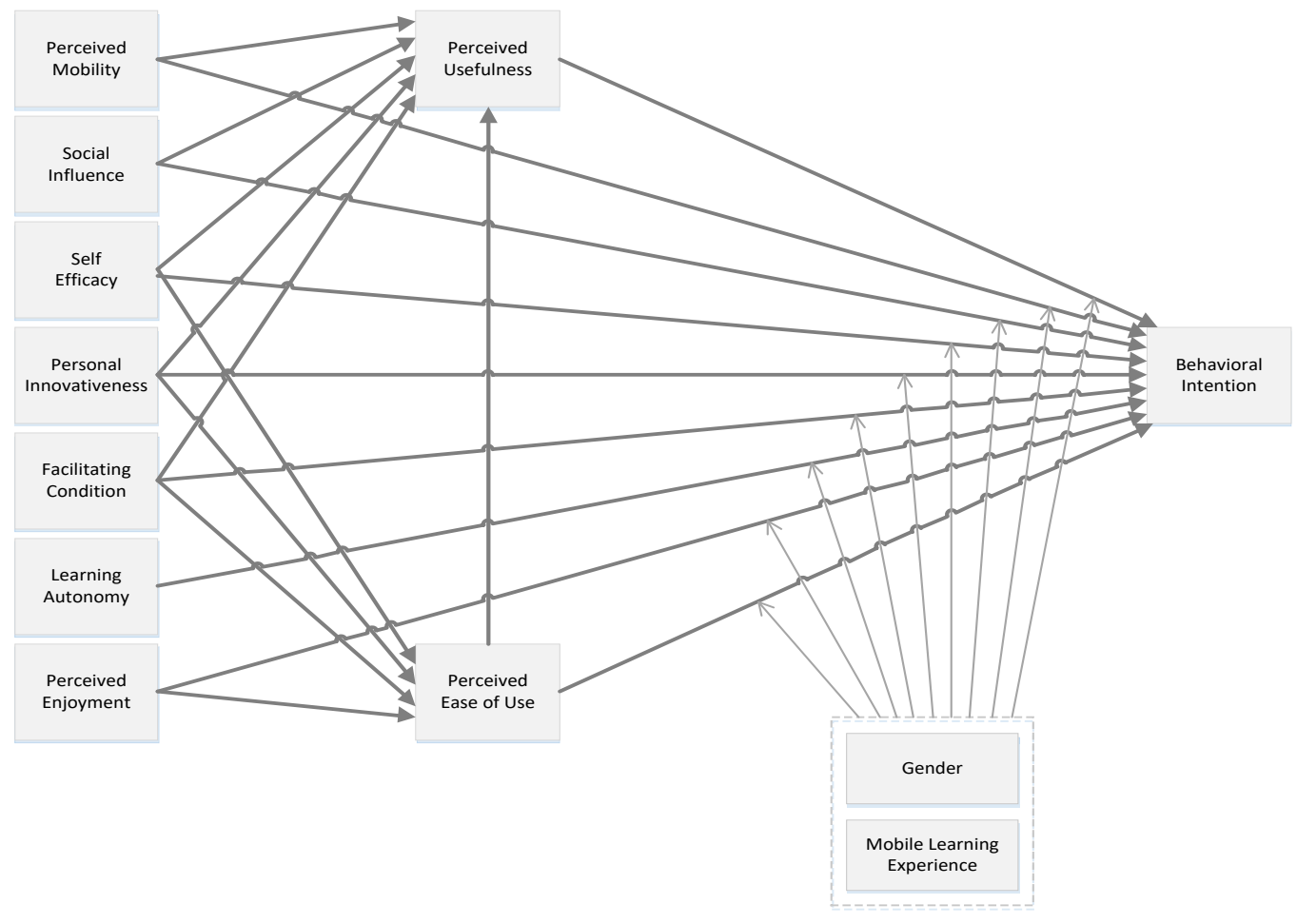

Figure 1: The theoretical model.

\section{RESEARCH HYPOTHESES}

There are 37 research hypotheses associated with the direct and moderating effects from the theoretical model. These hypotheses are presented in Table 4. The first 19 hypotheses, D1 to D19, concern direct causal effects among determinants of behavioral intention. The last 18 hypotheses, M20 to M37, concern the moderating factors of gender and mobile learning experience. The references identify previous studies that provide empirical support for the hypotheses. The term significant used in Table 4 refers to statistical significance at a level of 0.05 or less.

In the literature on technology adoption, with the exception of those based on Venkatesh et al. (2003), there are only a few previous studies that pay attention to moderating effects and even fewer that consider moderation in the context of the adoption of mobile learning systems. This study includes ten hypotheses concerned with moderating effects where there was no support in the literature related to mobile learning systems. However, in these cases the hypothesized moderating effects are considered to be logical and consequently they are described as exploratory hypotheses in relation to behavioral intentions to adopt mobile learning systems. 
Table 4: Research hypotheses associated with the proposed theoretical model

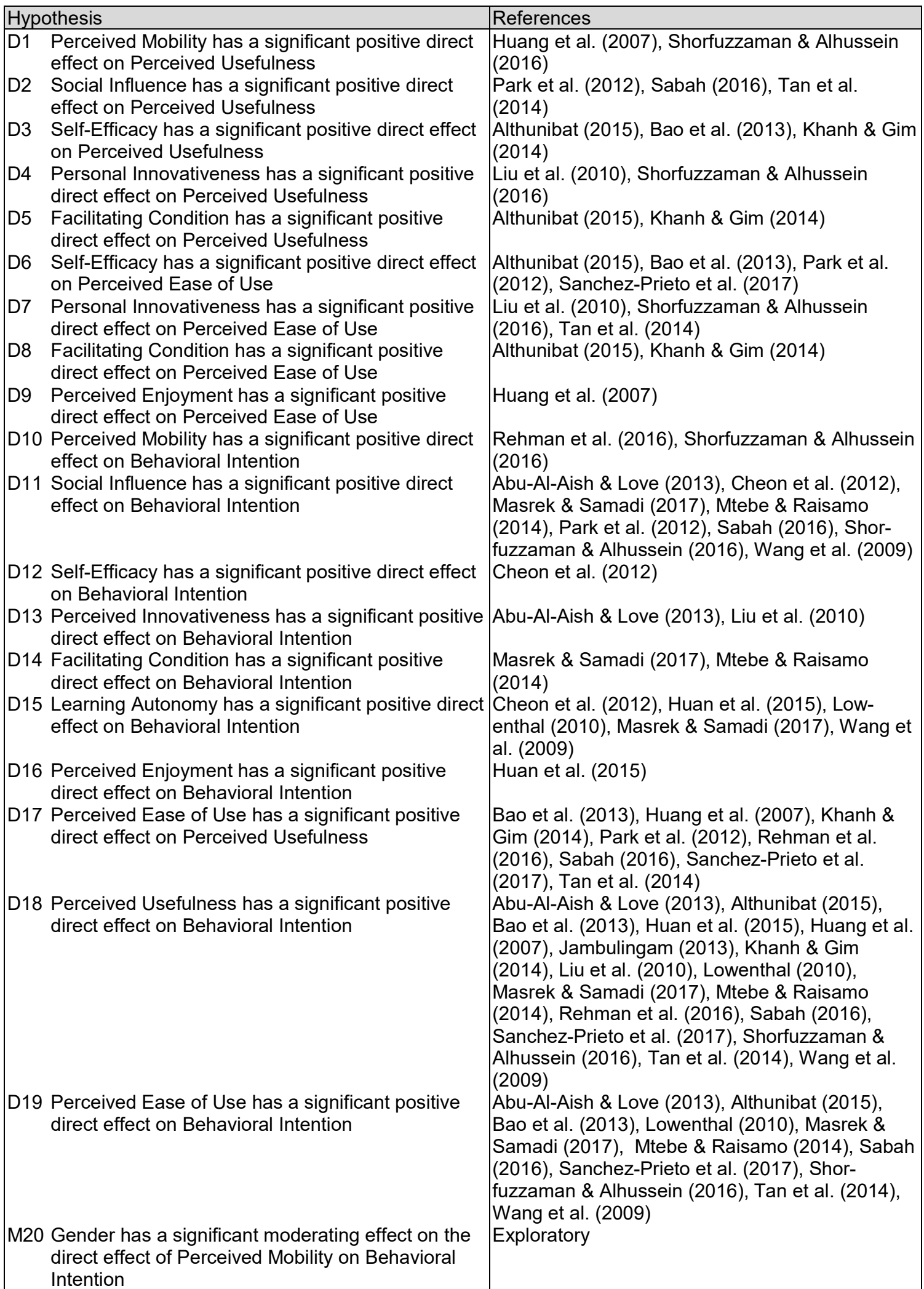




\begin{tabular}{|c|c|c|}
\hline \multirow{2}{*}{\multicolumn{2}{|c|}{$\begin{array}{l}\text { Hypothesis } \\
\text { M21 Gender has a significant moderating effect on the } \\
\text { direct effect of Social Influence on Behavioral In- } \\
\text { tention }\end{array}$}} & References \\
\hline & & Venkatesh et al. (2003), Wang et al. (2009) \\
\hline M22 & $\begin{array}{l}\text { Gender has a significant moderating effect on the } \\
\text { direct effect of Self-Efficacy on Behavioral Intention }\end{array}$ & Exploratory \\
\hline M23 & $\begin{array}{l}\text { Gender has a significant moderating effect on the } \\
\text { direct effect of Personal Innovativeness on Behav- } \\
\text { ioral Intention }\end{array}$ & Exploratory \\
\hline M24 & $\begin{array}{l}\text { Gender has a significant moderating effect on the } \\
\text { direct effect of Facilitating Condition on Behavioral } \\
\text { Intention }\end{array}$ & Venkatesh et al. (2012) \\
\hline M25 & $\begin{array}{l}\text { Gender has a significant moderating effect on the } \\
\text { direct effect of Learning Autonomy on Behavioral } \\
\text { Intention }\end{array}$ & Wang et al. (2009) \\
\hline M26 & $\begin{array}{l}\text { Gender has a significant moderating effect on the } \\
\text { direct effect of Perceived Enjoyment on Behavioral } \\
\text { Intention }\end{array}$ & Exploratory \\
\hline M27 & $\begin{array}{l}\text { Gender has a significant moderating effect on the } \\
\text { direct effect of Perceived Usefulness on Behavioral } \\
\text { Intention }\end{array}$ & Bao et al. (2013), Venkatesh et al. (2003) \\
\hline M28 & $\begin{array}{l}\text { Gender has a significant moderating effect on the } \\
\text { direct effect of Perceived Ease of use on Behav- } \\
\text { ioral Intention }\end{array}$ & Venkatesh et al. (2003) \\
\hline M29 & $\begin{array}{l}\text { Mobile learning experience has a significant mod- } \\
\text { erating effect on the direct effect of Perceived Mo- } \\
\text { bility on Behavioral Intention }\end{array}$ & Exploratory \\
\hline M30 & $\begin{array}{l}\text { Mobile learning experience has a significant mod- } \\
\text { erating effect on the direct effect of Social Influ- } \\
\text { ence on Behavioral Intention }\end{array}$ & Venkatesh et al. (2003) \\
\hline M31 & $\begin{array}{l}\text { Mobile learning experience has a significant mod- } \\
\text { erating effect on the direct effect of Self-Efficacy on } \\
\text { Behavioral Intention }\end{array}$ & Exploratory \\
\hline M32 & $\begin{array}{l}\text { Mobile learning experience has a significant mod- } \\
\text { erating effect on the direct effect of Personal Inno- } \\
\text { vativeness on Behavioral Intention }\end{array}$ & Exploratory \\
\hline M33 & $\begin{array}{l}\text { Mobile learning experience has a significant mod- } \\
\text { erating effect on the direct effect of Facilitating } \\
\text { Condition on Behavioral Intention }\end{array}$ & Venkatesh et al. (2012) \\
\hline M34 & $\begin{array}{l}\text { Mobile learning experience has a significant mod- } \\
\text { erating effect on the direct effect of Learning Au- } \\
\text { tonomy on Behavioral Intention }\end{array}$ & Exploratory \\
\hline M35 & $\begin{array}{l}\text { Mobile learning experience has a significant mod- } \\
\text { erating effect on the direct effect of Perceived En- } \\
\text { joyment on Behavioral Intention }\end{array}$ & Exploratory \\
\hline M36 & $\begin{array}{l}\text { Mobile learning experience has a significant mod- } \\
\text { erating effect on the direct effect of Perceived Use- } \\
\text { fulness on Behavioral Intention }\end{array}$ & Exploratory \\
\hline M37 & $\begin{array}{l}\text { Mobile learning experience has a significant mod- } \\
\text { erating effect on the direct effect of Perceived } \\
\text { Ease of use on Behavioral Intention }\end{array}$ & Venkatesh et al. (2003) \\
\hline
\end{tabular}

\section{RESEARCH DESIGN AND METHODOLOGY}

The study aims to develop theoretical and practical knowledge based on an individual's perceptions of the importance of the main variables associated with an individual's intentions to use mobile learning systems. These perceptions are measured at a single point in time using a self-administered questionnaire. This cross-sectional approach has been used successfully in previous studies of mobile learning. Decisions related to the design of the study followed the guidance provided by Neuman (2006). A field study method is used as an appropriate approach for measuring complex variables in 
situations where the influence of variables on the dependent variable cannot be controlled as in experimental designs (Boudreau, Gefen, \& Straub, 2001) and field studies identify effects on dependent variables which enhances the statistical results (Cook \& Campbell, 1979).

A questionnaire designed to measure the variables in the theoretical model and other variables used to determine a profile of the respondents was prepared in the English and Indonesian languages. Wherever possible the questionnaire used existing measuring instruments in order to improve the validity and reliability of the measures. The questionnaire was divided into two sections. Section 1 includes questions related to personal characteristics of the respondents such as age, gender, months of experience with mobile learning, the urban university at which they are registered, and their field of study at the university, the stage of their progress in their studies, and the mobile device they use to engage with mobile learning. Section 2 presents questions related to the other variables in the theoretical model. Both language versions of the questionnaire were reviewed by a focus group of users who were representative of the target population and who had expertise in both the English and Indonesian languages. Suggested modifications were included in revised versions of the questionnaires and the Indonesian language version was then administered in a pilot study using a sample of 10 suitable participants. Their responses and comments were noted and any modifications were incorporated into the final English and Indonesian versions of the questionnaire. The Indonesian language version was then used in the full study. A notated version of the questionnaire is included in the Appendix.

The subject of the study is a registered student in an urban university in Indonesia who is at least 18 years old and has at least one month of experience in using mobile learning. The size of the target population is unknown but certainly exceeds 100,000 . Consequently, with 5 percent precision and a confidence level of 95 percent a minimum sample size of 400 was determined

(http://www.webcitation.org/66kKEIC0b ). This sample size also satisfies the sample size needed to ensure the statistical validity of the study especially the structural equation modeling (SEM) analysis techniques used for the analyses and development of the theoretical model. The data was collected using a purposive (judgmental) sampling method which is appropriate in cases where individuals with particular characteristics are required (Neuman, 2006). The researcher distributed questionnaires to students from five universities with at least one university from each of four cities in Indonesia. These five universities were selected because they are typical of universities in urban areas of Indonesian cities. They are also representative of universities that place an emphasis on the use of mobile learning in their curricula. Contacts with these universities were made using personal contacts that the researcher has with staff from each of these five universities and involved the researcher attending each university to administer the questionnaires with the assistance of the staff. The selected universities all have approximately the same number of students and in light of the statistical validity of the study it was decided to obtain at least 100 completed questionnaires from each university giving a total sample size of at least 500 .

Questionnaire responses were entered in an SPSS worksheet and the accuracy of data entry was checked using a random selection of 10 percent of the sample. Any questionnaires that included missing values for any of the questions were discarded. Outlier values (i.e., a value three or more standard deviations from the mean) were identified and the corresponding respondent was removed from the sample. Using the criteria specified by Straub, Boudreau, and Gefen (2004), principle components factor analysis was used iteratively to assess the construct validity (discriminant and convergent) of the measures of the indicators for each of the latent model variables. Following the analysis of construct validity, the equivalence reliability of the measures of the indicators for each of the latent variables was examined using Cronbach alpha coefficients using criteria from George and Mallery (2003).

Following these data preparation procedures, a range of descriptive statistics was used to analyze the prepared data for the model variables (mean, standard deviation, skewness, and kurtosis). This analysis included the indicators for latent variables as well as a single scale measure for each latent variable, 
which was determined by calculating the weighted mean of the values of the indicators where the standard deviations of the indicators were used as the weights. This single scale measure of each latent variable was used in subsequent preliminary statistical analyses but not in the analyses of the theoretical model and its further development. In the model analyses the indicators for the latent variables were entered into the analyses and the single scale measures of these latent variables were not used in the model analyses. This is the correct procedure when, as described below, a latent structured regression measurement model is used as part of the SEM analysis. In particular, it was checked that the removal of outliers had produced distributions for the indicators for the model variables where the skewness and kurtosis were within acceptable limits of 3 and 7, respectively, which is required in order to justify the use of maximum likelihood estimation with subsequent structural equation modeling (SEM) analyses (Kline, 2016). Frequency distributions were used to analyze the responses in order to develop a profile of characteristics of the respondents.

$T$ tests were used to compare the mean values of the model variables: with the neutral value of 3 on their measurement scales; for male and female respondents; and for respondents with 37 months or more of mobile learning experience and those with 36 months or less experience. Pearson correlation coefficients were used to examine associations among the variables. In particular, statistically significant correlations helped to identify plausible additional causal effects that may be introduced into the theoretical model as a part of the development of the model. This was done noting that statistically significant correlations do not ensure cause and effect relationships, but provided there is also a clear temporal ordering associated with the variables they suggest the presence of a possible cause and effect relationship.

For the SEM analyses of the theoretical model three different measurement models were considered: path analysis (PA), partially latent structured regression (PLSR), and latent structured regression (LSR). Each of these models uses the same structural model of the causes and effects among the variables but each employs a different approach to the measurement of the variables. An important difference among these three measurement models concerns the way in which latent variables are treated. It was decided in this study to adopt a LSR measurement model, which incorporates the measurement of latent variables through the direct measurements of all of their indicators. The other two measurement models do not enter the measures of all of the indicators for latent variables into the analyses. Compared to the PA and PLSR models, the LSR model was considered to be the best in terms of measuring the complex nature of the constructs represented by each of the latent variables. In addition, Schumacker and Lomax (2016) indicate that the PA and PLSR models are best suited to mainly exploratory studies where there may not be established theory to support the structure of the model. However, in this study the structure of the model is supported by previous studies, and consequently the LSR measurement model is more appropriate. In addition, it was decided to use the common method of maximum likelihood estimation in the SEM analyses, which requires that the measures for skewness and kurtosis of the model variables have values within the acceptable limits of 3 and 7, respectively (Kline, 2016).

The SEM analyses were conducted using Amos computer software. All the procedures were carried out following Kline (2016). A range of fit statistics is used to assess the extent to which values of model characteristics determined from the estimates of parameters and the model structure are in agreement with the values of those characteristics estimated from the sample data. These fit statistics and the interpretation of their values are displayed in Appendix Table A1. The statistical significance of direct effects is reported routinely with Amos software but the statistical significance of indirect effects, the total of indirect effects, and the total of all effects are not. The statistical significance of indirect effects was determined using the heuristic from Cohen and Cohen (1983). The statistical significance of the total of indirect effects and the total of all effects was determined using the standard errors for these totals which were computed using nonparametric bootstrapping which is a feature of Amos. The recommended number of random samples for the bootstrapping procedure is 
at least 500 and in this study conservatively 1,000 random samples were used. In addition, the magnitudes of all of the standardized effects were interpreted using the heuristic from Cohen (1988).

The evaluation of moderation effects and the development of the theoretical model were done using the Group Analysis feature and the Specification Search facility, respectively, available in Amos software. The Group Analysis feature enables the statistical significance of the differences among the values of a direct effect for different groups to be determined. The Specification Search facility determines fit statistics for all models in a hierarchy formed by making selected direct effects optional in the theoretical model. For this analysis Kline (2016) recommends the final model to be the one with the minimum value for the fit statistic Normed Chi-square. In this study, optional direct effects were those that were small or not statistically significant in the initial SEM analysis of the theoretical model as well as plausible direct effects identified by the examination of correlation coefficients among the model variables.

\section{DATA PREPARATION AND DESCRIPTIVE ANALYSES}

\section{DATA PREPARATION}

A total of 725 responses were obtained from members of the target population. No data entry errors were found. One questionnaire included missing values and was removed from the sample. Furthermore, 28 questionnaires were found to include at least one outlier value for a model variable and they were removed from the sample to give a final sample size of 696 that satisfied the minimum sample size of 400 determined for the study.

Principal component factor analysis was used to test the construct validity of the measures of the 10 latent model variables. Appendix Table A2 displays the satisfactory results for the construct validity of the latent variables. Cronbach Alpha coefficients and their interpretations for the equivalence reliability of the sets of indicators are shown in Appendix Table A2 where it is seen that all the sets of indicators have satisfactory equivalence reliability.

Table 5 shows characteristics of the respondents including their age, gender, the university where they are registered, their field of study, the semester they are studying, and the main mobile device they use for mobile learning.

From Table 5 it is seen that: participants are predominately aged 18 to 22 years and are within their first seven semesters of university study; there is an adequate representation of males and females from each of the five universities; and participants are engaged in a range of fields of study. Mobile devices used are mainly smartphones followed by laptops and to tablets to a much less extent. Mobile learning experience is hypothesized as one of the moderating factors that may influence the determinants of the behavioral intention. The data showed that there are many respondents who have experience in mobile learning starting as early as their years in junior high-school. Figure 2 shows the distribution of mobile learning experience.

Table 5: Characteristics of the respondents

\begin{tabular}{|c|c|c|c|c|c|c|c|}
\hline Age in Years & Frequency & Percent & $\begin{array}{c}\text { Cumulative } \\
\text { Percent }\end{array}$ & Semester & Frequency & Percent & $\begin{array}{c}\text { Cumulative } \\
\text { Percent }\end{array}$ \\
\hline 18 & 137 & 19.7 & 19.7 & 1 & 133 & 19.1 & 19.1 \\
\hline 19 & 212 & 30.5 & 50.1 & 3 & 218 & 31.3 & 50.4 \\
\hline 20 & 188 & 27.0 & 77.2 & 4 & 41 & 5.9 & 56.3 \\
\hline 21 & 105 & 15.1 & 92.2 & 5 & 164 & 23.6 & 79.9 \\
\hline 22 & 34 & 4.9 & 97.1 & 6 & 2 & .3 & 80.2 \\
\hline 23 & 9 & 1.3 & 98.4 & 7 & 111 & 15.9 & 96.1 \\
\hline 24 & 11 & 1.6 & 100.0 & 8 & 4 & .6 & 96.7 \\
\hline Total & 696 & 100.0 & & 9 & 23 & 3.3 & 100.0 \\
\hline \multicolumn{4}{|c|}{ Mean Age $=19.65$ years, Standard Deviation $=1.30$} & Total & 696 & 100.0 & \\
\hline
\end{tabular}




\begin{tabular}{|c|c|c|c|c|c|}
\hline Gender & Frequency & Percent & $\begin{array}{l}\text { Main Mobile } \\
\text { Device }\end{array}$ & quency & Percent \\
\hline Male & 371 & 53.3 & Smartphone & 485 & 69.7 \\
\hline Female & 325 & 46.7 & Tablet & 30 & 4.3 \\
\hline Total & 696 & 100.0 & Laptop & 181 & 26.0 \\
\hline University & Frequency & Percent & Total & 696 & 100.0 \\
\hline University of Surabaya & 155 & 22.3 & Field of Study & Frequency & Percent \\
\hline Atma Jaya University & 121 & 17.4 & Science and Engineering & 250 & 35.9 \\
\hline Yogyakarta & & & Business and Economics & 205 & 29.5 \\
\hline Satya Wacana University & 170 & 24.4 & & & \\
\hline Salatiga & & & Art and Design & 109 & 15.7 \\
\hline Soegijapranata University & 131 & 18.8 & & & \\
\hline Semarang & & & Social, Law, Communica- & 132 & 19.0 \\
\hline $\begin{array}{l}\text { Stikubank University Se- } \\
\text { marang }\end{array}$ & 119 & 17.1 & tion, Humanity & 696 & 1000 \\
\hline Total & 696 & 100.0 & & & \\
\hline
\end{tabular}

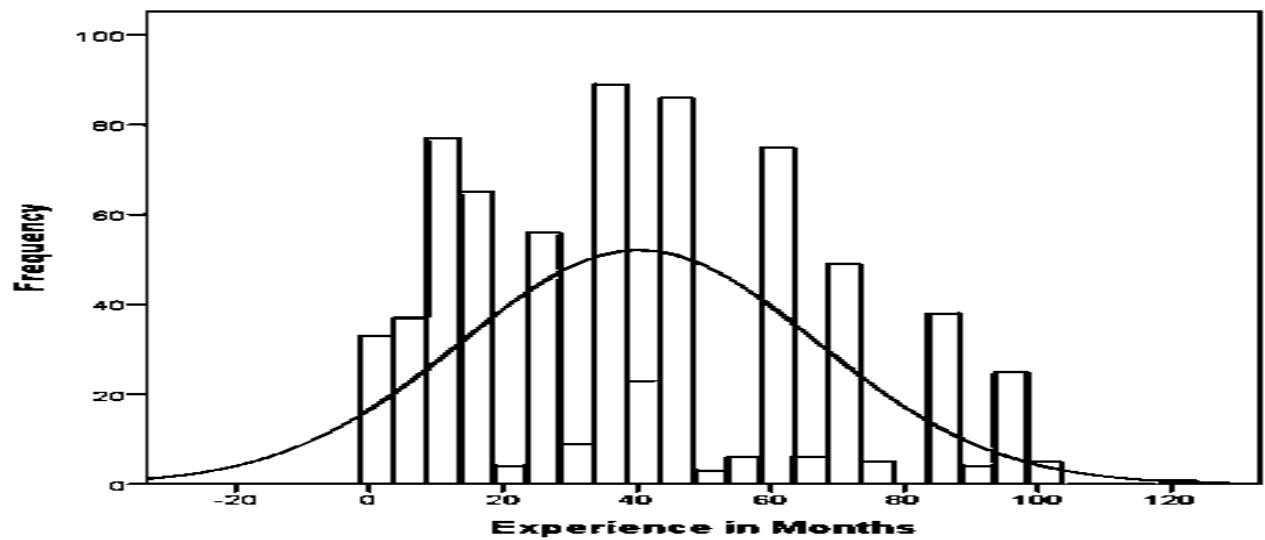

Figure 2: Distribution for mobile learning experience in month

The range of mobile learning experience is from 1 month up to 120 months with a mean of 40 months, a standard deviation of 27 months, and a median of 36 months. Consequently, it was considered appropriate to form two groups for the moderator: (1) those with mobile learning experience of 36 months or less (361 respondents)referred to as the less experienced group; and (2) those with more than 36 months of mobile learning experience (335 respondents) referred to as the more experienced group. These groups represent 51.9 percent and 48 percent of the respondents, respectively.

\section{DESCRIPTIVE ANALYSES}

Descriptive statistics for the latent variables and their indicators are displayed in Table 6.

Table 6: Descriptive statistics for model variables

\begin{tabular}{|c|c|c|c|c|c|c|c|c|c|}
\hline $\begin{array}{l}\text { Variable } 1 \\
\text { Indicator }\end{array}$ & Mean & $\begin{array}{l}\text { Std. Devi } \\
\text { ation }\end{array}$ & Skewness & Kurtosis & $\begin{array}{l}\text { Variable } 1 \\
\text { Indicator }\end{array}$ & Mean & $\begin{array}{c}\text { Std. Devi } \\
\text { ation }\end{array}$ & Skewness & Kurtosis \\
\hline PM & 4.28 & .484 & -.175 & -.838 & LA & 3.56 & .680 & .050 & -.421 \\
\hline PM1 & 4.36 & .602 & -.352 & -.667 & LA1 & 3.68 & .788 & -.088 & -.451 \\
\hline PM2 & 4.37 & .627 & -.481 & -.653 & LA2 & 3.42 & .797 & .221 & -.299 \\
\hline PM3 & 4.25 & .615 & -.214 & -.590 & LA3 & 3.51 & .786 & -.038 & -.420 \\
\hline PM4 & 4.13 & .644 & -.131 & -.632 & LA4 & 3.62 & .759 & .037 & -.411 \\
\hline $\mathrm{SI}$ & 3.41 & .579 & .230 & .317 & $\mathrm{PE}$ & 3.85 & .611 & .199 & -.335 \\
\hline SI1 & 3.23 & .701 & .404 & .235 & PE1 & 3.86 & .697 & .036 & -.614 \\
\hline $\mathrm{SI} 2$ & 3.29 & .710 & .304 & .012 & PE2 & 3.92 & .676 & -.157 & -.181 \\
\hline SI3 & 3.36 & .726 & .030 & -.299 & PE3 & 3.79 & .716 & .150 & -.706 \\
\hline SI4 & 3.79 & .642 & -.068 & -.142 & PE4 & 3.83 & .710 & .038 & -.590 \\
\hline
\end{tabular}




\begin{tabular}{|lllll|lllll|}
\hline $\begin{array}{l}\text { Variable I } \\
\text { Indicator }\end{array}$ & Mean & $\begin{array}{c}\text { Std. Devi- Skewness } \\
\text { ation }\end{array}$ & & & Kurtosis & \multicolumn{2}{l}{$\begin{array}{l}\text { Variable I } \\
\text { Indicator }\end{array}$} & $\begin{array}{c}\text { Mean } \\
\text { Std. Devi- Skewness } \\
\text { ation }\end{array}$ & Kurtosis \\
\hline SE & 3.87 & .610 & .059 & -.469 & PU & 3.95 & .617 & -.106 & -.538 \\
SE1 & 3.95 & .711 & -.092 & -.588 & PU1 & 4.19 & .624 & -.164 & -.563 \\
SE2 & 3.79 & .735 & -.019 & -.500 & PU2 & 3.98 & .766 & -.327 & -.375 \\
SE3 & 3.99 & .678 & -.239 & -.095 & PU3 & 3.89 & .737 & -.015 & -.730 \\
SE4 & 3.74 & .727 & .165 & -.652 & PU4 & 3.78 & .736 & .095 & -.656 \\
\hline PI & 3.67 & .657 & .054 & -.495 & PEU & 3.58 & .528 & .076 & -.039 \\
PI1 & 3.73 & .769 & -.029 & -.507 & PEU1 & 3.77 & .677 & .032 & -.381 \\
PI2 & 3.76 & .785 & -.064 & -.554 & PEU2 & 3.80 & .669 & .001 & -.337 \\
PI3 & 3.30 & .756 & .232 & -.105 & PEU3 & 3.94 & .636 & -.122 & -.054 \\
PI4 & 3.90 & .740 & -.154 & -.469 & PEU4 & 3.91 & .659 & -.051 & -.333 \\
\hline FC & 3.78 & .501 & .180 & -.042 & BI & 4.08 & .584 & -.124 & -.476 \\
FC1 & 3.74 & .655 & .081 & -.381 & BI1 & 4.22 & .653 & -.260 & -.726 \\
FC2 & 3.90 & .633 & -.084 & -.105 & BI2 & 4.00 & .695 & -.155 & -.480 \\
FC3 & 3.73 & .644 & .098 & -.386 & BI3 & 4.05 & .669 & -.177 & -.379 \\
FC4 & 3.74 & .649 & .067 & -.353 & BI4 & 4.07 & .686 & -.246 & -.338 \\
\hline
\end{tabular}

Table 6 shows that the magnitudes of skewness and kurtosis are within the acceptable limits of 3 and 7, respectively, required for the use of maximum likelihood estimation in SEM analyses (Kline, 2016).

$\mathrm{T}$ tests showed that:

(a) The mean value of each latent variable was significantly greater than the neutral value of 3 ( $p<$ 0.05 ) which indicated that all of these variables were considered to be important for mobile learning;

(b) The only significant differences $(\mathrm{p}<0.05)$ between the mean values of model variables for males and females indicated that compared to females, the males (i) are more confident in their capability to use a mobile device to engage in learning tasks (Self-Efficacy); (ii) have a more positive intention to adopt mobile learning in their study (Personal Innovativeness); (iii) have a stronger belief that there is organizational and technical infrastructure to support the use of mobile learning systems (Facilitating Condition); (iv) find mobile learning more enjoyable (Perceived Enjoyment); and (v) find mobile learning easier to use (Perceived Ease of Use).

(c) The only significant differences $(p<0.05)$ between the mean values of model variables for the group with 36 months or less mobile learning experience and the more experienced group indicated that compared to the less experienced group, the more experienced group (i) place more importance on the value of mobility of devices used to access and check information anywhere and at any time (Perceived Mobility); (ii) find mobile learning more enjoyable (Perceived Enjoyment); and (iii) have a stronger belief that using a mobile learning system enhances their learning performances (perceived Usefulness).

Table 7 displays the correlation coefficients associated with model variables.

Table 7: Correlations

\begin{tabular}{|c|c|c|c|c|c|c|c|c|c|c|c|}
\hline Variable & EXP & PM & SI & SE & $\mathbf{P I}$ & FC & LA & $\mathrm{PE}$ & PU & PEU & $\mathrm{B}$ \\
\hline M-Learning Experience (EXP) & 1 & & & & & & & & & & \\
\hline Perceived Mobility (PM) & 140 & 1 & & & & & & & & & \\
\hline Social Influence (SI) & .031 & .289 & 1 & & & & & & & & \\
\hline Self-Efficacy (SE) & .062 & .363 & .269 & 1 & & & & & & & \\
\hline Personal Innovativeness (PI) & -.031 & 108 & 157 & .375 & 1 & & & & & & \\
\hline Facilitating Condition (FC) & .070 & 334 & 248 & .574 & 268 & 1 & & & & & \\
\hline Learning Autonomy (LA) & -.045 & 108 & .087 & 169 & 280 & .198 & 1 & & & & \\
\hline Perceived Enjoyment (PE) & .086 & .465 & 324 & .345 & 252 & .395 & 186 & 1 & & & \\
\hline Perceived Usefulness (PU) & .105 & .459 & .309 & .303 & .219 & .370 & .277 & .656 & 1 & & \\
\hline Perceived Ease of Use (PEU) & .053 & .388 & .256 & .479 & 278 & .508 & .234 & .509 & .489 & 1 & \\
\hline Behavioral Intention (BI) & .062 & .356 & .289 & 384 & 274 & .409 & .219 & .505 & .575 & 479 & 1 \\
\hline
\end{tabular}


In Table 7, shaded cells identify correlation coefficients associated with the direct causal effects in the theoretical model. It is seen that:

(a) All of 19 direct causal effects in the theoretical model are associated with a statistically significant correlation $(\mathrm{p}<0.05)$;

(b) All of the correlations among the latent variables are statistically significant $(\mathrm{p}<0.05)$ and positive;

(c) Those with large (small) amounts of experience with mobile learning systems find them more (less) enjoyable and useful to use and they place a high (low) value on the mobility provided by these systems;

(d) There are statistically significant correlations that are not associated with causal effects in the theoretical model and some of these suggest additional plausible causal effects that need to be considered in the subsequent SEM analyses and development of the theoretical model. Effects are considered plausible if the correlation between the variables is statistically significant $(\mathrm{p}<$ 0.05 ) and it is logical to assume that the cause precedes the effect in time. However, it is noted that significant correlations do not ensure significant causal effects but only suggest such effects. The possible additional plausible causal effects are the following: (1) Learning Autonomy $\rightarrow$ Perceived Usefulness, (2) Perceived Enjoyment $\rightarrow$ Perceived Usefulness, (3) Perceived Mobility $\rightarrow$ Perceived Ease of Use, (4) Social Influence $\rightarrow$ Perceived Ease of Use, (5) Learning Autonomy $\rightarrow$ Perceived Ease of Use.

\section{MODEL ANALYSIS AND DEVELOPMENT}

\section{ANALYSIS OF THE THEORETICAL MODEL}

The theoretical model was analyzed using AMOS software and the direct causal effects on Behavioral Intention are shown in Figure 3 where the effects are presented in the following format:

(a) The unstandardized effect is shown first followed by its statistical significance using *, **, and $* * *$ to indicate statistical significance at a level of $0.05,0.01$, and 0.001 , respectively. NS indicates not statistically significant at a level of 0.05 or less.

(b) In parentheses, the standardized effect is shown first followed by an interpretation of the magnitude of the standardized effect described by Cohen (1988) as: Small (S) (less than 0.1); Medium (M) (0.1 to less than 0.5$)$; or Large (L) (0.5 or greater).

(c) The same notation is also used in Figure 4 (The Direct effects of the final model) and Table 10 (Full analysis of the final model). 


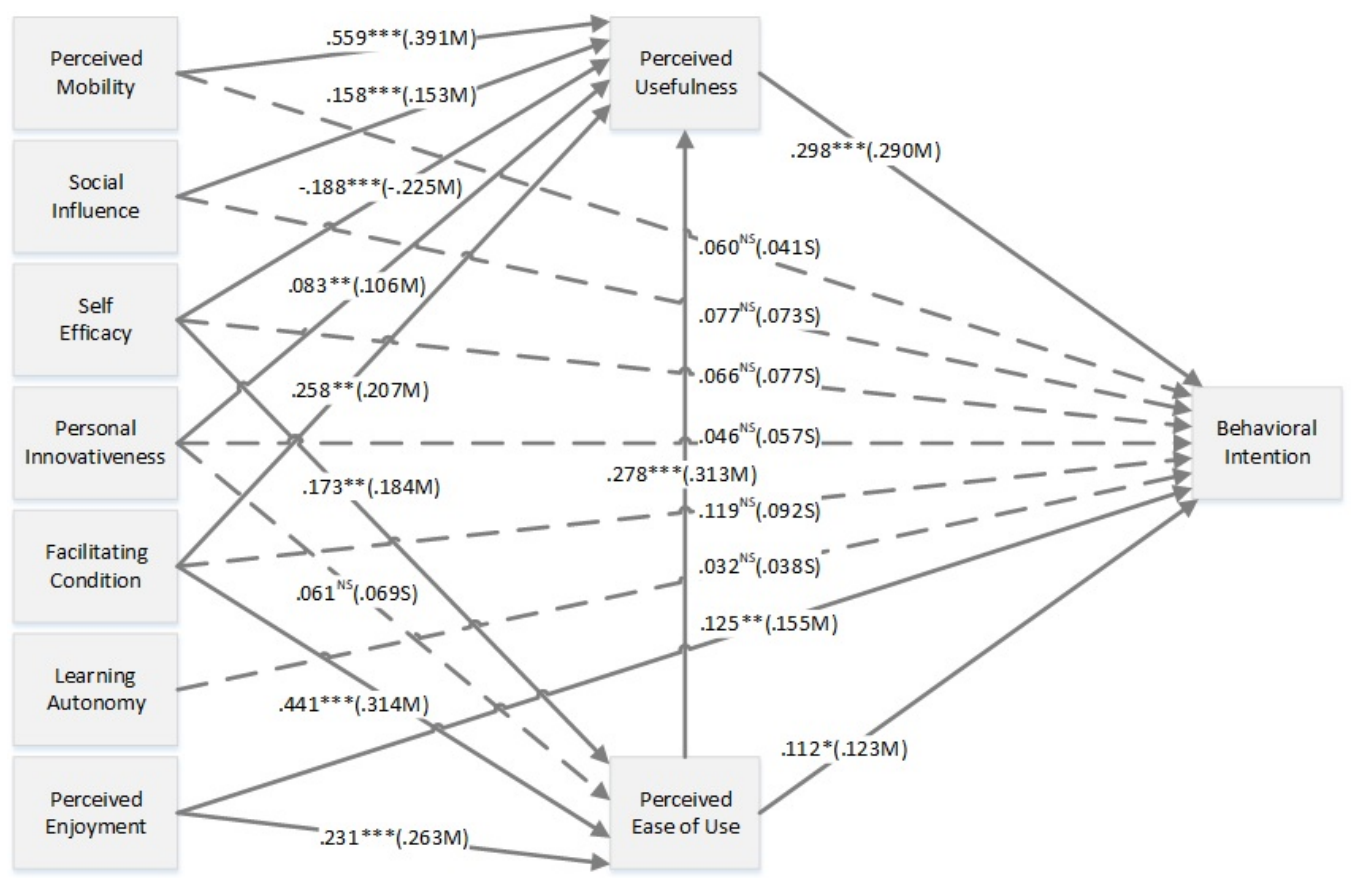

Figure 3: The direct effects of the theoretical model.

The range of fit statistics for the theoretical model is displayed in Table 8.

Table 8: Fit statistics for the theoretical model

\begin{tabular}{|lllllllll|}
\hline $\mathrm{N}$ & $\mathrm{NC}\left(\mathrm{X}^{2} / \mathrm{df}\right)$ & $\mathrm{RMR}$ & $\mathrm{GFI}$ & AGFI & $\mathrm{NFI}$ & IFI & CFI & RMSEA \\
\hline 696 & $1599.653 / 700=2.285$ & .025 & .896 & .878 & .905 & .944 & .944 & .043 \\
& $\mathrm{R}^{2}: \mathrm{PU}(.481), \mathrm{PEU}(.430)$, and $\mathrm{BI}(.442)$ \\
\hline
\end{tabular}

From Table 8 it is seen that the fit statistics have generally acceptable values although the values of GFI and AGFI could be improved. Also, noting the small effects in Figure 3, which are not statistically significant, and the possible additional causal effects identified by correlations in Table 7, it is evident that the model in Figure 3 may be further developed to form a simpler final model with improved fit statistics.

\section{DEVELOPMENT OF THE THEORETICAL MODEL}

The seven direct effects that are not statistically significant in Figure 3 are considered for removal from the theoretical model. Furthermore, five causal effects identified in Table 7 are considered as plausible additions to the theoretical model. These 12 direct effects were made optional in the theoretical model which produced a hierarchy of $2^{12}$ (4096) possible models. The Specification Search feature in Amos was used to analyze the hierarchy of models and following Kline (2016) the model with smallest value of Normed Chi-square (NC) was selected as the final model. The final model is shown in Figure 4. 


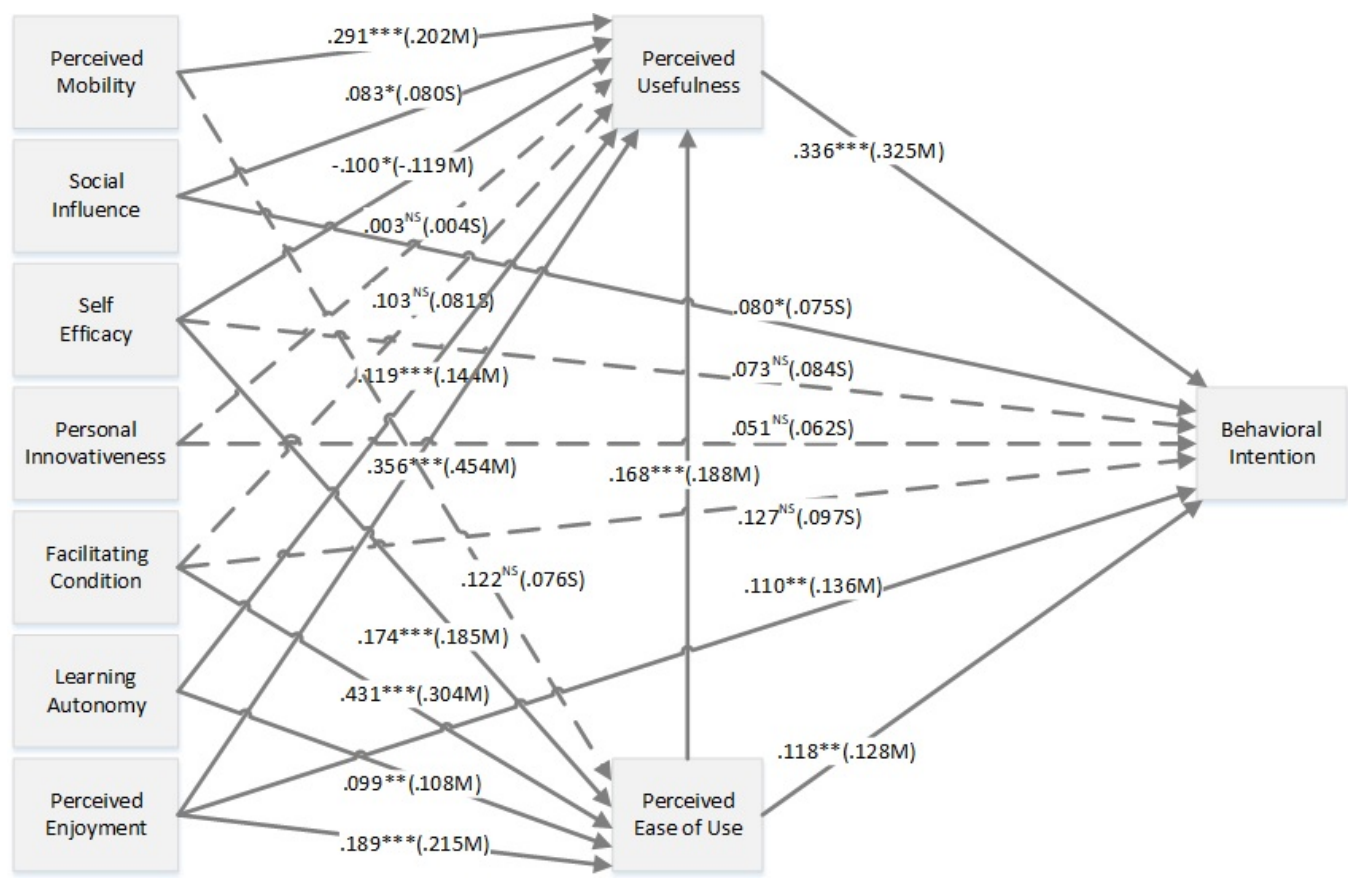

Figure 4: The direct effects of the final model.

The final model included four of the five proposed additional direct effects (Learning Autonomy $\rightarrow$ Perceived Usefulness, Perceived Enjoyment $\rightarrow$ Perceived Usefulness, Perceived Mobility $\rightarrow$ Perceived Ease of Use, and Learning Autonomy $\rightarrow$ Perceived Ease of Use). Three of the seven direct effects considered for removal were not included in the final model (Perceived Mobility $\rightarrow$ Behavioral Intention, Learning Autonomy $\rightarrow$ Behavioral Intention, and Personal Innovativeness $\rightarrow$ Perceived Ease of Use). In the final model the number of direct effects that are not statistically significant at a level of 0.05 or less is also reduced from seven to six (Perceived Mobility $\rightarrow$ Perceived Ease of Use, Personal Innovativeness $\rightarrow$ Perceived Usefulness, Facilitating Condition $\rightarrow$ Perceived Usefulness, Self-Efficacy $\rightarrow$ Behavioral Intention, Personal Innovativeness $\rightarrow$ Behavioral Intention, and Facilitating Condition $\rightarrow$ Behavioral Intention). All of these six effects are small in magnitude. However, if any of these are removed then the value of Normed Chi-square (NC) increases. The fit statistics associated with the final model are displayed in Table 9.

Table 9: Fit statistics for the final model

\begin{tabular}{|lllllllll|}
\hline $\mathrm{N}$ & $\mathrm{NC}\left(\mathrm{X}^{2} / \mathrm{df}\right)$ & $\mathrm{RMR}$ & $\mathrm{GFI}$ & $\mathrm{AGFI}$ & $\mathrm{NFI}$ & $\mathrm{IFI}$ & $\mathrm{CFI}$ & $\mathrm{RMSEA}$ \\
\hline 696 & $1467.026 / 699=2.099$ & .020 & .903 & .886 & .913 & .952 & .952 & .040 \\
& $\mathrm{R}^{2}: \mathrm{PU}(.588), \mathrm{PEU}(.430)$, and BI (.453) \\
\hline
\end{tabular}

The fit statistics for the final model in Table 9 are improved compared to the fit statistics for the theoretical model in Table 8.

\section{FULL ANALYSIS OF THE FINAL MODEL}

Table 10 presents a complete analysis of the final model showing the statistical significance of all of the effects. 
Table 10: Full analysis for the final model

\begin{tabular}{|c|c|c|c|c|}
\hline \multirow[t]{2}{*}{ Variable } & \multirow[t]{2}{*}{ Effect } & \multicolumn{2}{|l|}{ Intervening } & \multirow{2}{*}{$\begin{array}{l}\text { Dependent } \\
\text { Behavioral Intention (BI) }\end{array}$} \\
\hline & & $\begin{array}{l}\text { Perceived Useful- } \\
\text { ness (PU) }\end{array}$ & $\begin{array}{l}\text { Perceived Ease of } \\
\text { Use (PEU) }\end{array}$ & \\
\hline $\begin{array}{l}\text { Perceived } \\
\text { Mobility } \\
\text { (PM) }\end{array}$ & $\begin{array}{l}\text { Direct } \\
\text { Indirect } \\
\text { Total Indirect } \\
\text { Total }\end{array}$ & $\begin{array}{l}.291^{* \star *}(.202 \mathrm{M}) \\
\text { PM-PEU-PU } \\
.020^{\mathrm{NS}}(.014 \mathrm{~S}) \\
.020^{\mathrm{NS}}(.014 \mathrm{~S}) \\
.311^{* \star \star}(.216 \mathrm{M})\end{array}$ & $\begin{array}{l}.122^{\mathrm{NS}}(.076 \mathrm{~S}) \\
\text { Nil } \\
\text { Nil } \\
.122^{\mathrm{NS}}(.076 \mathrm{~S})\end{array}$ & $\begin{array}{l}\text { Nil } \\
\text { PM-PU-BI .098 } \\
\text { PM-PEU-PU-BI } .007^{\text {NS }}(.005 S) \\
\text { PM-PEU-BI } .014^{\text {NS }}(.010 \mathrm{~S}) \\
.119^{* * *}(.081 \mathrm{~S}) \\
.119^{* * *}(.081 \mathrm{~S})\end{array}$ \\
\hline $\begin{array}{l}\text { Social } \\
\text { Influence } \\
\text { (SI) }\end{array}$ & $\begin{array}{l}\text { Direct } \\
\text { Indirect } \\
\text { Total Indirect } \\
\text { Total }\end{array}$ & $\begin{array}{l}.083^{*}(.080 S) \\
\text { Nil } \\
\text { Nil } \\
.083^{*}(.080 S)\end{array}$ & $\begin{array}{l}\text { Nil } \\
\text { Nil } \\
\text { Nil } \\
\text { Nil }\end{array}$ & $\begin{array}{l}.080^{\star}(.075 \mathrm{~S}) \\
\text { SI-PU-BI .028* }(.026 \mathrm{~S}) \\
.028^{\star}(.026 \mathrm{~S}) \\
.108^{\star \star}(.101 \mathrm{M})\end{array}$ \\
\hline $\begin{array}{l}\text { Self- } \\
\text { Efficacy } \\
\text { (SE) }\end{array}$ & $\begin{array}{l}\text { Direct } \\
\text { Indirect } \\
\text { Total Indirect } \\
\text { Total }\end{array}$ & $\begin{array}{l}-.100^{*}(-.119 S) \\
\text { SE-PEU-PU } \\
.029^{* \star *}(.035 S) \\
.029^{\star}(.035 S) \\
-.071^{N S}(-.084 S)\end{array}$ & $\begin{array}{l}.174^{* \star *}(.185 \mathrm{M}) \\
\text { Nil } \\
\text { Nil } \\
.174^{* * *}(.185 \mathrm{M})\end{array}$ & $\begin{array}{l}.073^{\text {NS }}(.084 S) \\
\text { SE-PU-BI }-.034^{*}(-.039 S) \\
\text { SE-PEU-PU-BI } .010^{* * *}(.011 S) \\
\text { SE-PEU-BI } .021^{* *}(.024 S) \\
-.003^{\text {NS }}(-.004 S) \\
.070^{\text {NS }}(.080 S)\end{array}$ \\
\hline $\begin{array}{l}\text { Personal } \\
\text { Innova- } \\
\text { tiveness } \\
(\mathrm{PI})\end{array}$ & $\begin{array}{l}\text { Direct } \\
\text { Indirect } \\
\text { Total Indirect } \\
\text { Total }\end{array}$ & $\begin{array}{l}.003^{\mathrm{NS}}(.004 \mathrm{~S}) \\
\mathrm{Nil} \\
\mathrm{Nil} \\
.003^{\mathrm{NS}}(.004 \mathrm{~S})\end{array}$ & $\begin{array}{l}\text { Nil } \\
\text { Nil } \\
\text { Nil } \\
\text { Nil }\end{array}$ & $\begin{array}{l}.051^{\mathrm{NS}}(.062 \mathrm{~S}) \\
\mathrm{PI}-\mathrm{PU}-\mathrm{BI} .001^{\mathrm{NS}}(.001 \mathrm{~S}) \\
.001^{\mathrm{NS}}(.001 \mathrm{~S}) \\
.052^{\mathrm{NS}}(.063 \mathrm{~S})\end{array}$ \\
\hline $\begin{array}{l}\text { Facilitating } \\
\text { Condition } \\
\text { (FC) }\end{array}$ & $\begin{array}{l}\text { Direct } \\
\text { Indirect } \\
\text { Total Indirect } \\
\text { Total } \\
\end{array}$ & $\begin{array}{l}.103^{\mathrm{NS}}(.081 \mathrm{~S}) \\
\text { FC-PEU-PU } \\
.072^{* *}(.057 \mathrm{~S}) \\
.072^{* *}(.057 \mathrm{~S}) \\
.175^{*}(.138 \mathrm{M})\end{array}$ & $\begin{array}{l}.431^{* * *}(.304 \mathrm{M}) \\
\text { Nil } \\
\text { Nil } \\
.431^{* * *}(.304 \mathrm{M})\end{array}$ & $\begin{array}{l}.127^{\mathrm{NS}}(.097 \mathrm{~S}) \\
\text { FC-PU-BI .035 } 5^{\mathrm{NS}}(.026 \mathrm{~S}) \\
\text { FC-PEU-PU-BI } .024^{* * *}(.019 \mathrm{~S}) \\
\text { FC-PEU-BI .051 } \\
.110^{* *}(.084 \mathrm{~S}) \\
.237^{* *}(.181 \mathrm{M})\end{array}$ \\
\hline $\begin{array}{l}\text { Learning } \\
\text { Autonomy } \\
\text { (LA) }\end{array}$ & $\begin{array}{l}\text { Direct } \\
\text { Indirect } \\
\text { Total Indirect } \\
\text { Total }\end{array}$ & $\begin{array}{l}.119^{* * *}(.144 \mathrm{M}) \\
\text { LA-PEU-PU } \\
.017^{* *}(.020 S) \\
.017^{\star}(.020 S) \\
.136^{* * \star}(.164 \mathrm{M})\end{array}$ & $\begin{array}{l}.099^{\star *}(.108 \mathrm{M}) \\
\text { Nil } \\
\text { Nil } \\
.099^{\star *}(.108 \mathrm{M})\end{array}$ & 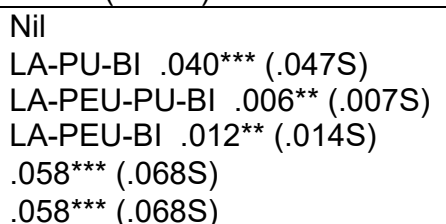 \\
\hline $\begin{array}{l}\text { Perceived } \\
\text { Enjoyment } \\
\text { (PE) }\end{array}$ & $\begin{array}{l}\text { Direct } \\
\text { Indirect } \\
\text { Total Indirect } \\
\text { Total }\end{array}$ & $\begin{array}{l}.356^{* * *}(.454 \mathrm{M}) \\
\text { PE-PEU-PU } \\
.032^{* \star *}(.040 S) \\
.032^{* *}(.040 \mathrm{~S}) \\
.388^{* * *}(.494 \mathrm{M})\end{array}$ & $\begin{array}{l}.189^{* \star *}(.215 \mathrm{M}) \\
\text { Nil } \\
\text { Nil } \\
.189^{* * *}(.215 \mathrm{M})\end{array}$ & 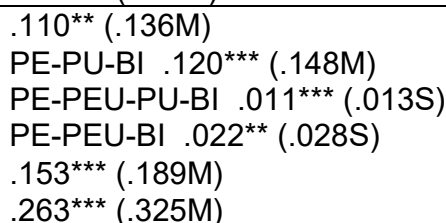 \\
\hline $\begin{array}{l}\text { Perceived } \\
\text { Useful- } \\
\text { ness } \\
\text { (PU) }\end{array}$ & $\begin{array}{l}\text { Direct } \\
\text { Indirect } \\
\text { Total Indirect } \\
\text { Total }\end{array}$ & $\begin{array}{l}\text { Nil } \\
\text { Nil } \\
\text { Nil } \\
\text { Nil }\end{array}$ & $\begin{array}{l}\text { Nil } \\
\text { Nil } \\
\text { Nil } \\
\text { Nil }\end{array}$ & $\begin{array}{l}.336^{* * *}(.325 \mathrm{M}) \\
\mathrm{Nil} \\
\mathrm{Nil} \\
.336^{* * *}(.325 \mathrm{M})\end{array}$ \\
\hline $\begin{array}{l}\text { Perceived } \\
\text { Ease of } \\
\text { Use (PEU) }\end{array}$ & $\begin{array}{l}\text { Direct } \\
\text { Indirect } \\
\text { Total Indirect } \\
\text { Total }\end{array}$ & $\begin{array}{l}.168^{* * *}(.188 \mathrm{M}) \\
\text { Nil } \\
\text { Nil } \\
.168^{* * *}(.188 \mathrm{M})\end{array}$ & $\begin{array}{l}\mathrm{Nil} \\
\mathrm{Nil} \\
\mathrm{Nil} \\
\mathrm{Nil}\end{array}$ & $\begin{array}{l}.118^{* \star}(.128 \mathrm{M}) \\
\text { PEU-PU-BI .056 } \\
.056^{\star \star}(.061 \mathrm{~S}) \\
.174^{\star \star *}(.189 \mathrm{M})\end{array}$ \\
\hline
\end{tabular}

Among the results in Table 10 there are several that emphasize the need to examine the statistical significance of indirect effects and the total of all effects in order to obtain a full understanding of influences on Behavioral Intention: (a) Although Perceived Mobility and Learning Autonomy does not have a direct effect it does have a total effect which is statistically significant; (b) Self-Efficacy has some indirect effects which are statistically significant even though its direct effect and total effect are 
not statistically significant; and (c) The total of indirect effects due to Perceived Enjoyment is greater than the direct effect.

\section{MODERATING EFFECTS}

Gender and Mobile Learning Experience have been hypothesized to have significant moderating effects on nine direct causal effects on Behavioral Intention in the theoretical model in Figure 3. Table 11 presents the results of analyzing the moderating effects using the group analysis function available in Amos software.

Table 11: The moderating effects of gender and mobile learning experience

\begin{tabular}{|c|c|c|c|c|c|c|c|c|c|c|}
\hline \multirow[b]{2}{*}{ Gender } & \multicolumn{4}{|c|}{ Males $(\mathrm{N}=371)$} & \multicolumn{4}{|c|}{ Females $(\mathrm{N}=325)$} & \multicolumn{2}{|c|}{ Difference } \\
\hline & 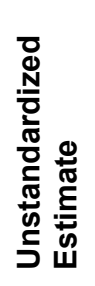 & 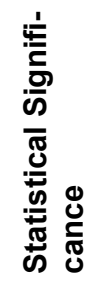 & 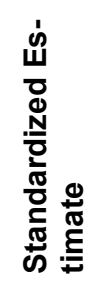 & 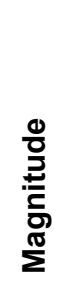 & 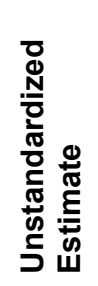 & 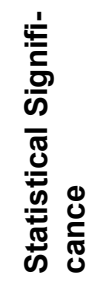 & 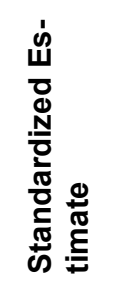 & $\begin{array}{l}\frac{0}{0} \\
\frac{0}{2} \\
\frac{\underline{t}}{5} \\
\frac{0}{\Sigma} \\
\sum^{\pi}\end{array}$ & 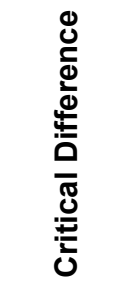 & 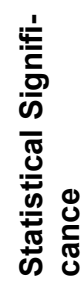 \\
\hline $\mathrm{PM} \rightarrow \mathrm{BI}$ & .048 & NS & .033 & $\mathrm{~s}$ & .117 & NS & .081 & $\mathrm{~s}$ & 0.442 & NS \\
\hline $\mathrm{SI} \rightarrow \mathrm{BI}$ & .051 & NS & .048 & $\mathrm{~s}$ & .095 & NS & .092 & $\mathrm{~S}$ & 0.536 & NS \\
\hline $\mathrm{SE} \rightarrow \mathrm{BI}$ & .085 & NS & .093 & $\mathrm{~s}$ & .009 & NS & .010 & $\mathrm{~s}$ & -0.678 & NS \\
\hline $\mathrm{PI} \rightarrow \mathrm{BI}$ & .052 & NS & .060 & $\mathrm{~s}$ & .094 & NS & .122 & M & 0.629 & NS \\
\hline $\mathrm{FC} \rightarrow \mathrm{BI}$ & .106 & NS & .083 & $\mathrm{~S}$ & .157 & NS & .118 & M & 0.305 & NS \\
\hline $\mathrm{LA} \rightarrow \mathrm{BI}$ & .115 & $* *$ & .135 & M & -.091 & NS & -.111 & M & -3.294 & $* * *$ \\
\hline $\mathrm{PE} \rightarrow \mathrm{BI}$ & .054 & NS & .067 & $\mathrm{~s}$ & .191 & $* * *$ & .242 & $\mathrm{M}$ & 1.741 & NS \\
\hline $\mathrm{PU} \rightarrow \mathrm{BI}$ & .342 & $* * *$ & .314 & M & .230 & ** & .243 & M & -1.004 & NS \\
\hline $\mathrm{PEU} \rightarrow \mathrm{BI}$ & .165 & $* *$ & .182 & M & .066 & NS & .070 & $S$ & -1.049 & NS \\
\hline \multirow[b]{2}{*}{$\begin{array}{c}\text { Mobile } \\
\text { Learning } \\
\text { Experience }\end{array}$} & \multicolumn{4}{|c|}{ Less-Experienced $(\mathrm{N}=361)$} & \multicolumn{4}{|c|}{ More-Experienced ( $\mathrm{N}=335)$} & \multicolumn{2}{|c|}{ Difference } \\
\hline & 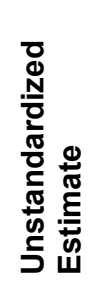 & 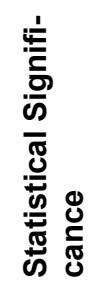 & 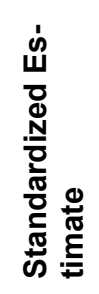 & 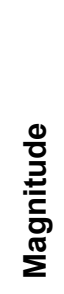 & 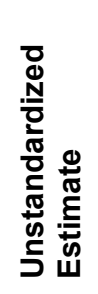 & 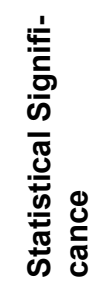 & 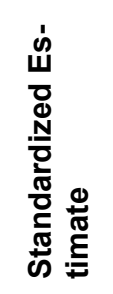 & 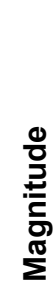 & 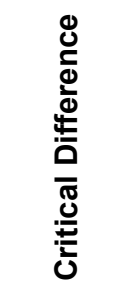 & 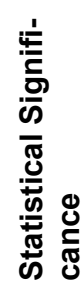 \\
\hline $\mathrm{PM} \rightarrow \mathrm{BI}$ & .033 & NS & .023 & $S$ & .050 & NS & .034 & $\mathrm{~S}$ & 0.107 & NS \\
\hline & .079 & NS & .071 & $\mathrm{~S}$ & .064 & NS & .064 & $\mathrm{~S}$ & -0.175 & NS \\
\hline $\mathrm{SE} \rightarrow \mathrm{BI}$ & .023 & NS & .028 & $\mathrm{~s}$ & .126 & NS & .142 & M & 0.878 & NS \\
\hline $\mathrm{PI} \rightarrow \mathrm{BI}$ & .022 & NS & .027 & $S$ & .074 & NS & .093 & $S$ & 0.768 & NS \\
\hline $\mathrm{FC} \rightarrow \mathrm{BI}$ & .177 & NS & .144 & M & .047 & NS & .034 & $\mathrm{~s}$ & -0.671 & NS \\
\hline $\mathrm{LA} \rightarrow \mathrm{BI}$ & .073 & NS & .091 & $S$ & -.006 & NS & -.007 & $S$ & -1.266 & NS \\
\hline $\mathrm{PE} \rightarrow \mathrm{BI}$ & .122 & * & .149 & M & .133 & * & .169 & M & 0.133 & NS \\
\hline $\mathrm{PU} \rightarrow \mathrm{BI}$ & .346 & $* * *$ & .324 & M & .251 & ** & .250 & M & -0.824 & NS \\
\hline $\mathrm{PEU} \rightarrow \mathrm{BI}$ & .113 & NS & .130 & M & .117 & NS & .119 & M & 0.044 & NS \\
\hline
\end{tabular}

In Table 11 the only significant moderating effect is due to gender which moderates the direct effect of Learning Autonomy on Behavioral Intention. Table 12 displays the fit statistics for the moderator groups. 
Table 12: Fit statistics for the two moderator groups

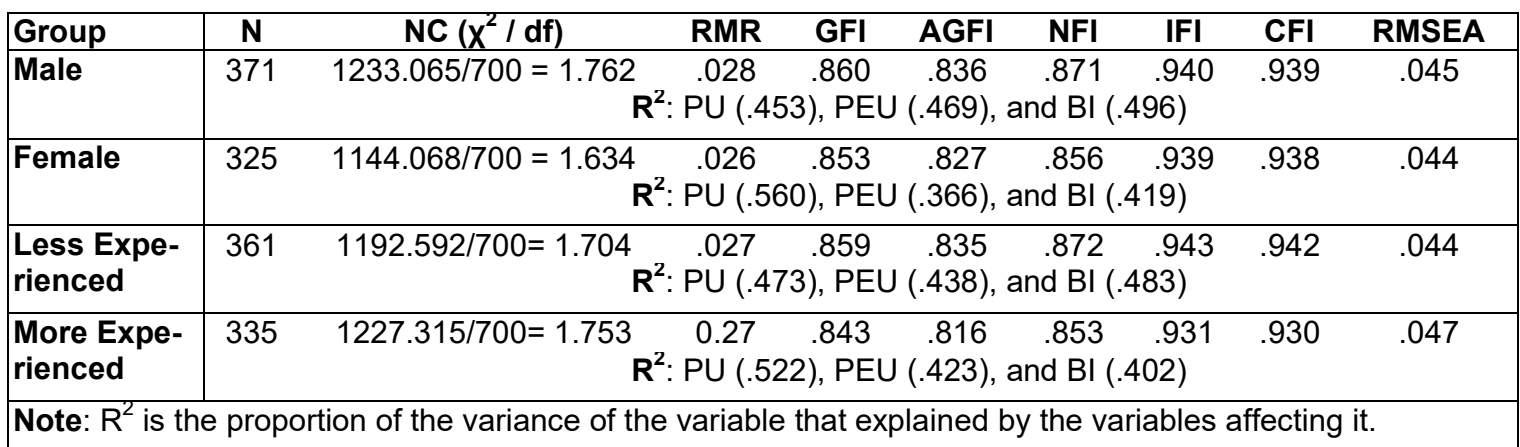

Overall, the fit statistics GFI, AGFI, and NFI are not greater than 0.9 for any of the groups while the other fit statistics are satisfactory and in each case satisfactory proportions of the variance of the endogenous variables are explained. Consequently, it is not claimed that the model is a satisfactory fit with the data for any particular group among the moderators.

\section{DISCUSSION OF THE FINDINGS}

Considering the total effects on Behavioral Intention in Table 10 it is seen that consistent with prior studies (Huan et al., 2015; Wang et al., 2009), this study confirmed that Perceived Usefulness (an intervening variable) and Perceived Enjoyment (an exogenous variable) are the two most important influences on Behavioral Intention. These are followed by the effects of the three variables Perceived Ease of Use (the other intervening variable), and two exogenous variables Facilitating Condition and Social Influence. Small and relatively unimportant effects are due to Perceived Mobility, Self-Efficacy, Learning Autonomy, and Personal Innovativeness which are all exogenous variables.

\section{COMPARISON OF THE FINDINGS WITH RESULTS FROM PREVIOUS STUDIES}

Table 13(a) presents the findings in the final model related to the research hypotheses presented in Table 4. There are 10 hypotheses fully supported by the findings of this study (D1, D2, D6, D8, D9, D11, D16, D17, D18, and D19), which means that the null hypotheses stating no statistically significant effects have been rejected. These fully supported hypotheses confirm the importance of many direct effects reported in previous studies.

Furthermore, there are eight hypotheses which were partially supported by the findings of the study (D4, D5, D7, D10, D12, D13, D14, and D15). Partially supported means that, although the hypothesized statistically significant direct causal effect was not found (i.e., the null hypothesis stating no statistically significant direct effect was not rejected), there was a statistically significant correlation between the two variables in the hypothesis even though this does not imply a statistically significant causal effect. This highlights the need for these hypotheses to be retested in further studies.

The hypothesis D3 in Table 4 proposed that Self-Efficacy has a statistically significant positive direct effect on Perceived Usefulness. The final model shows that the direct effect is statistically significant but negative and from Table 7 the correlation between these two variables is statistically significant and positive. Consequently D3 is considered to be neither fully or partially supported. This situation is often associated with negative suppression where the normal solution would be to remove SelfEfficacy from the model (Maassen \& Bakker, 2001). However, rather than remove Self-Efficacy from the final model it was decided to present this finding as a result that needs to be retested in further studies. Otherwise, Self-Efficacy also has a significant positive indirect effect on Perceived Usefulness through the mediation effect of Perceived Ease of Use, resulting in a negative total effect which is not statistically significant. 
Table 13(a): The findings related to the causal effect hypotheses

\begin{tabular}{|c|c|c|}
\hline \multicolumn{3}{|c|}{ Hypothesis } \\
\hline D1 & Perceived Mobility has a significant positive direct effect on Perceived Usefulness & \multirow{10}{*}{$\begin{array}{l}\text { Fully sup- } \\
\text { ported }\end{array}$} \\
\hline D2 & Social Influence has a significant positive direct effect on Perceived Usefulness & \\
\hline D6 & Self-Efficacy has a significant positive direct effect on Perceived Ease of Use & \\
\hline D8 & Facilitating Condition has a significant positive direct effect on Perceived Ease of Use & \\
\hline D9 & Perceived Enjoyment has a significant positive direct effect on Perceived Ease of Use & \\
\hline D11 & Social Influence has a significant positive direct effect on Behavioral Intention & \\
\hline D16 & Perceived Enjoyment has a significant positive direct effect on Behavioral Intention & \\
\hline D17 & Perceived Ease of Use has a significant positive direct effect on Perceived Usefulness & \\
\hline D18 & Perceived Usefulness has a significant positive direct effect on Behavioral Intention & \\
\hline D19 & Perceived Ease of Use has a significant positive direct effect on Behavioral Intention & \\
\hline D4 & Personal Innovativeness has a significant positive direct effect on Perceived Usefulness & \multirow{8}{*}{$\begin{array}{l}\text { Partially } \\
\text { supported }\end{array}$} \\
\hline D5 & Facilitating Condition has a significant positive direct effect on Perceived Usefulness & \\
\hline D7 & Personal Innovativeness has a significant positive direct effect on Perceived Ease of Use & \\
\hline D10 & Perceived Mobility has a significant positive direct effect on Behavioral Intention & \\
\hline D12 & Self-Efficacy has a significant positive direct effect on Behavioral Intention & \\
\hline D13 & Perceived Innovativeness has a significant positive direct effect on Behavioral Intention & \\
\hline D14 & Facilitating Condition has a significant positive direct effect on Behavioral Intention & \\
\hline D15 & Learning Autonomy has a significant positive direct effect on Behavioral Intention & \\
\hline D3 & Self-Efficacy has a significant positive direct effect on Perceived Usefulness & $\begin{array}{l}\text { Not fully } \\
\text { or partially } \\
\text { supported }\end{array}$ \\
\hline
\end{tabular}

Table 13(b) represents five additional hypotheses (A1 to A5) associated with direct causal effects that were tested in the production of the final model using the specification search procedure. Hypotheses A1, A2, and A4 were fully supported while hypotheses A3 and A5 were only partially supported. Hypothesis A5 was associated with a proposed additional direct effect in the theoretical model which was not included in the final model following the specification search.

Table 13(b): Additional causal effect hypotheses introduced in the final model

\begin{tabular}{|l|l|l|}
\hline \multicolumn{3}{|l|}{ Hypothesis } \\
\hline A1 & Learning Autonomy has a significant positive direct effect on Perceived Usefulness & $\begin{array}{l}\text { Fully sup- } \\
\text { ported }\end{array}$ \\
A2 & Perceived Enjoyment has a significant positive direct effect on Perceived Usefulness & \\
A4 & Learning Autonomy has a significant positive direct effect on Perceived Ease of Use & Partially \\
A3 & Perceived Mobility has a significant positive direct effect on Perceived Ease of Use & supported \\
\hline A5 & Social Influence has a significant positive direct effect on Perceived Ease of Use & Note: Shaded cell is the additional hypothesis that is not included in the final model. \\
\hline
\end{tabular}

Throughout, the term "significant" used in these Tables 13(a) and 13(b) refers to statistical significance at a level of 0.05 or less.

\section{MODERATING EFFECTS OF GENDER AND MOBILE LEARNING EXPERIENCE}

Gender and Mobile Learning Experience are hypothesized to have a moderating effect on the direct effects of nine variables on Behavioral Intention, listed as hypotheses M20 to M37 in Table 4. Results in Table 11 show that Gender has a significant moderating effect only on the direct effect of Learning Autonomy on Behavioral Intention. This direct effect is significant for males but not for females. Mobile Learning Experience does not have any significant moderating effect on any of the nine direct effects on Behavioral Intention. 


\section{NEW FINDINGS NOT REPORTED IN PREVIOUS STUDIES}

Table 14 presents findings which have not been reported in prior studies. It is important that further studies examine these new results.

Table 14: New findings

\begin{tabular}{|rr|r|}
\hline 1. Learning Autonomy does: \\
a. Have a statistically significant direct effect on Perceived Usefulness; \\
b. Have a statistically significant indirect effect on Perceived Usefulness through the media- \\
tion effects of Perceived Ease of Use; \\
c. Have a statistically significant direct effect on Perceived Ease of Use; \\
d. Not have a statistically significant direct effect on Behavioral Intention; \\
e. Have a statistically significant indirect effect on Behavioral Intention through the mediation \\
effects of Perceived Usefulness and Perceived Ease of Use.
\end{tabular}

Prior studies have shown that Learning Autonomy has a significant direct effect on Behavioral Intention. However, the findings of this study indicate that Learning Autonomy has a statistically significant indirect effect only on Behavioral Intention via the mediating variables Perceived Usefulness and Perceived Ease of Use. The models proposed in those prior studies investigate the direct effect of Learning Autonomy on Behavioral Intention without considering the possible effects of Learning Autonomy with other determinants. However, in this study Learning Autonomy has significant direct effects on the intervening variables Perceived Usefulness and Perceived Ease of Use.

Perceived Enjoyment is one of the two most important determinants of Behavioral Intention. Prior studies have shown that Perceived Enjoyment has a significant direct effect on Perceived Ease of Use and Behavioral Intention. However, there is no empirical evidence from prior studies in the context of mobile learning that there is a direct causal effect between Perceived Enjoyment and Perceived Usefulness. The findings of this study indicate that Perceived Enjoyment has a significant direct ef- 
fect on Perceived Usefulness. Furthermore, when compared to other variables Perceived Enjoyment has the strongest influence on Perceived Usefulness.

Facilitating Condition is hypothesized to have direct effects on Perceived Usefulness, Perceived Ease of Use, and Behavioral Intention. However, the findings of this study indicate that Facilitating Condition has a direct causal effect on Perceived Ease of Use only. Facilitating Condition does not have any direct effects on Perceived Usefulness or to Behavioral Intention but it does have significant indirect effects on both variables.

Perceived Mobility is hypothesized to have direct effects on Perceived Usefulness and Behavioral Intention. However, the findings of this study indicate that Perceived Mobility has a direct causal effect on Perceived Usefulness only. Perceived Mobility does not have any direct effect on Behavioral Intention but it does have a significant indirect effect on Behavioral Intention via the mediating variables Perceived Usefulness and Perceived Ease of Use. Also, it is noted that Perceived Mobility has a significant positive correlation with Perceived Ease of Use.

Social Influence is the only variable in this study with the same results as prior studies where it has significant direct effects on Perceived Usefulness and Behavioral Intention. In addition, Social Influence is found to have a significant correlation with Perceived Ease of Use and also to have a significant indirect effect on Behavioral Intention through the mediation role of Perceived Usefulness.

Self-Efficacy is hypothesized to have direct effects on Perceived Usefulness, Perceived Ease of Use, and Behavioral Intention. However, the findings of this study indicate that Self-Efficacy has direct causal effect with Perceived Ease of Use only.

Personal Innovativeness is hypothesized to have direct effects on Perceived Usefulness, Perceived Ease of Use, and Behavioral Intention. However, the findings of this study indicate that Personal Innovativeness has no direct causal effect with any of those variables.

\section{PRACTICAL IMPLICATIONS OF THE FINDINGS}

Perceived Enjoyment and Perceived Usefulness are the two most important factors affecting behavioral intention. This implies that successful adoption of mobile learning in a university requires the decision makers in charge to ensure the students find mobile learning both useful and enjoyable.

The other three influential factors are Perceived Ease of Use, Facilitating Condition, and Social Influence. This implies that specific actions need to be done in order to ensure that the use of mobile learning is free of effort. The management of the university has to facilitate and support the mobile learning system and infrastructure and they also need to create a university learning environment where professors, senior students, and friends all encourage the adoption of mobile learning.

Table 15 describes practical means associated with actions aimed to increase the behavioral intention to adopt mobile learning based on the findings. The actions are organized in a decreasing order of effect on this objective. The model variables associated with each action is also identified. Actions and model variables with small total effects on behavioral intention are excluded from Table 15 in order to focus on the objective and primary associated actions. Based on the analyses of moderating effects of Gender and Mobile Learning Experience in Table 11 any specific groups that should be targeted in order to achieve the stated action are identified. 
Table 15: Practical objectives and associated actions to increase behavioral intention to adopt mobile learning

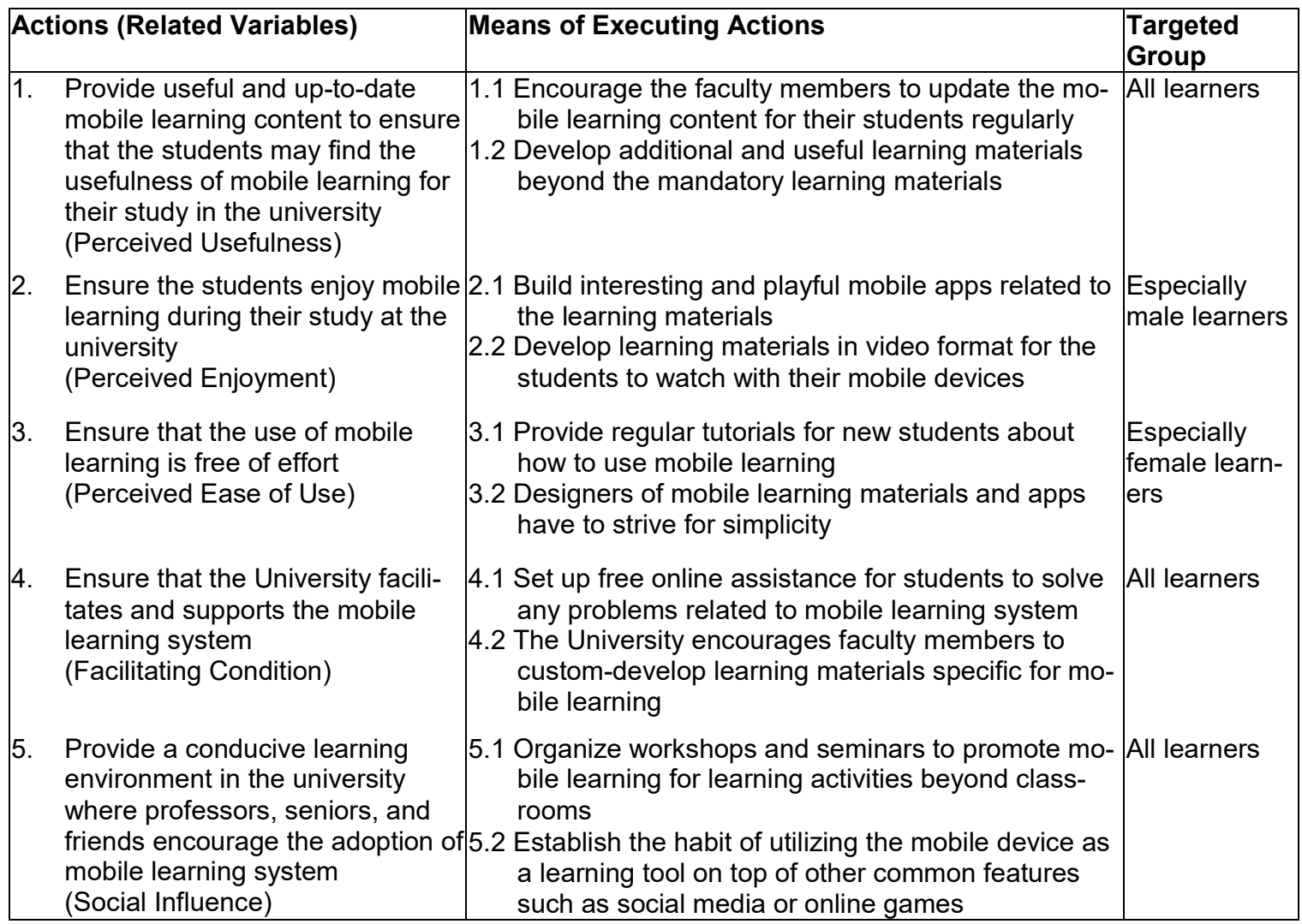

\section{CONCLUSION}

This study contributes to understanding the adoption of mobile learning in two important ways. Different from previous studies: moderating effects due to Gender and Mobile Learning Experience are examined; and a complete analysis of causal effects is presented based not only on direct effects but also indirect effects and the totals of effects.

From a theoretical perspective, among the nine variables in the final model which have an influence on Behavioral Intention, two variables (Perceived Usefulness and Perceived Enjoyment) have the strongest influence followed by the influences of the three variables (Perceived Ease of Use, Facilitating Condition, and Social Influence). The standardized total effects due to these five variables are all medium in magnitude with values ranging from 0.101 to 0.325 and their unstandardized total effects are all statistically significant at a level of 0.01 or less. The remaining four variables (Perceived Mobility, Learning Autonomy, Self-Efficacy, and Personal Innovativeness) have only small total effects on Behavioral Intention. Their standardized total effects range from 0.063 to 0.081 , and, while the standardized total effects of Perceived Mobility and Learning Autonomy are statistically significant at a level of 0.001 , the standardized total effects of the other two variables are not statistically significant at a level of 0.05 or less. In the final model 45 percent of the variance of Behavioral Intention was explained by the variables that affect it, and the fit statistics for the model are all very satisfactory. Overall, the results supported many of the findings about direct effects in previous studies. In addition, the correlations between Behavioral Intention and each of the nine variables affecting it were found to be positive correlation and statistically significant at a level of 0.05 or less. Attention is drawn to new insights which are presented in Table 14, especially those that are based on the analyses of significant correlations and indirect effects among variables. 
The only statistically significant moderating effect at a level of 0.05 or less due to Gender concerned the direct effect of Learning Autonomy on Behavioral Intention. This direct effect was statistically significant at a level of 0.01 for males but not statistically significant at a level of 0.05 or less for females. Mobile Learning Experience did not have any statistically significant moderating effects at a level of 0.05 or less.

From a practical perspective, actions designed to improve the adoption of mobile learning were determined based on the important influences on Behavioral Intention associated with Perceived Usefulness, Perceived Enjoyment, Perceived Ease of Use, Facilitating Condition, and Social Influence. The analyses of moderating effects identified target groups that should receive particular attention in relation to these actions.

The study followed a rigorous and statistically valid quantitative approach using descriptive statistics and SEM analyses to develop a final model from an initial theoretical model that was derived from findings in previous studies. However, there are limitations on the findings. The external validity can only be validated by repeating the study and this is strongly recommended. The examination of moderator effects was considered to be exploratory in nature due to the lack of previous studies of mobile learning that considered moderators. The findings for moderators need to be verified in further studies. The suspected negative suppression effect involving the direct effect of Self-Efficacy on Perceived Usefulness needs to be reexamined, and the new findings from this study (Table14) require verification.

This study may be extended by investigating: the effects of different groupings within the moderators; the inclusion of different moderators, model variables, and causal effects; subjects from rural Indonesian universities where the infrastructure and facilities are inferior to those in urban universities; and comparisons with findings obtained from studies conducted in different cultural contexts.

\section{ACKNOWLEDGEMENT}

The author gratefully acknowledges the support from the Ministry of Research, Technology, and Higher Education of the Republic of Indonesia and the Ministry of Finance of the Republic of Indonesia with the grant of BUDI LN LPDP 2016 PhD Scholarship at Assumption University of Thailand, Registration Number: 20160822018876, as well as the support from Sekolah Tinggi Teknik Surabaya (STTS), Indonesia.

\section{REFERENCES}

Abu-Al-Aish, A., \& Love, S. (2013). Factors influencing students' acceptance of m-learning: An investigation in higher education. The International Review of Research in Open and Distributed Learning, 14(5), 85-107. https://doi.org/10.19173/irrodl.v14i5.1631

Agarwal, R., \& Prasad, J. (1998). A conceptual and operational definition of personal innovativeness in the domain of information technology. Information Systems Research, 9(2), 204-215. https://doi.org/10.1287/isre.9.2.204

Ajzen, I. (1991). The theory of planned behavior. Organizational Behavior and Human Decision Processes, 50(2), 179211. https://doi.org/10.1016/0749-5978(91)90020-T

Althunibat, A. (2015). Determining the factors influencing students' intention to use m-learning in Jordan higher education. Computers in Human Behavior, 52, 65-71. https://doi.org/10.1016/j.chb.2015.05.046

Bandura, A. (1977). Self-efficacy: toward a unifying theory of behavioral change. Psychological Review, 84(2), 191 215. https://doi.org/10.1037/0033-295X.84.2.191

Bandura, A. (1986). The explanatory and predictive scope of self-efficacy theory. Journal of Social and Clinical Psychology, 4(3), 359-373. https://doi.org/10.1521/jscp.1986.4.3.359 
Bao, Y., Xiong, T., Hu, Z., \& Kibelloh, M. (2013). Exploring gender differences on general and specific computer self-efficacy in mobile learning adoption. Journal of Educational Computing Research, 49(1), 111-132. https://doi.org/10.2190/EC.49.1.e

Boudreau, M., Gefen, D., \& Straub, D. (2001). Validation in IS research: A state-of-the-art assessment. Management Information System Quarterly, 25(1), 1-16. https://doi.org/10.2307/3250956

Cheon, J., Lee, S., Crooks, S. M., \& Song, J. (2012). An investigation of mobile learning readiness in higher education based on the theory of planned behavior. Computers and Education, 59(3), 1054-1064. https://doi.org/10.1016/i.compedu.2012.04.015

Cohen, J. (1988). Statistical power analysis for the behavioral sciences (2nd ed.). New York: Academic Press.

Cohen, J., \& Cohen, P. (1983). Applied multiple regression / correlation analysis for the behavioral sciences (3rd ed.). Mahwah, N.J.: Erlbaum.

Compeau, D. R., \& Higgins, C. A. (1995). Computer self-efficacy: Development of a measure and initial test. Management Information Systems Quarterly, 19(2), 189-211. https://doi.org/10.2307/249688

Cook, T. D., \& Campbell, D. T. (1979). Quasi-experimentation: Design and analysis issues for field settings. Boston: Houghton Mifflin.

Cross, J. (2004). An informal history of eLearning. On the Horizon, 12(3), 103-110. https://doi.org/10.1108/10748120410555340

Davis, F. D. (1989). Perceived usefulness, perceived ease of use and user acceptance of information technology. Management Information Systems Quarterly, 13(3), 319-340. https://doi.org/10.2307/249008

Davis, F. D., Bagozzi, R. P., \& Warshaw, P. R. (1992). Extrinsic and intrinsic motivation to use computers in the workplace. Journal of Applied Social Psychology, 22(14), 1111-1132. https://doi.org/10.1111/j.15591816.1992.tb00945.x

George, D., \& Mallery, P. (2003). SPSS for windows step by step: A simple guide and reference. 11.0 update. Boston: Allyn and Bacon.

Huan, Y., Li, X.P., Aydeniz, M., \& Wyatt, T. (2015). Mobile learning adoption: An empirical investigation for engineering education. International Journal of Engineering Education, 31(4), 1081-1091.

Huang, J. H., Lin, Y. R., \& Chuang, S. T. (2007). Elucidating user behavior of mobile learning: A perspective of the extended technology acceptance model. The Electronic Library, 25(5), 585-598. https://doi.org/10.1108/02640470710829569

Jambulingam, M. (2013). Behavioural intention to adopt mobile technology among tertiary students. World Applied Sciences Journal, 22(9), 1262-1271.

Khan, B. (2005). Managing e-learning strategies: Design, delivery, implementation and evaluation. Hershey, PA: Information Science Publishing. https://doi.org/10.4018/978-1-59140-634-1

Khanh, N. T. V., \& Gim, G. (2014). Factors influencing mobile learning adoption intention: An empirical investigation in high education. Journal of Social Sciences, 10(2), 51-62. https://doi.org/10.3844/jssp.2014.51.62

Kline, R. B. (2016). Principles and practice of structural equation modeling (4th ed.). London: Guilford Press.

Kukulska-Hulme, A. (2009). Will mobile learning change language learning? ReCALL: The Journal of EURO CALL, 21(2), 157-165.

Kwon, S., \& Lee, J. E. (2010). Design principles of m-learning for ESL. Procedia Social and Behavioral Sciences, 2(2), 1884-1889. https://doi.org/10.1016/j.sbspro.2010.03.1003

Liu, Y., Li, H., \& Carlsson, C. (2010). Factors driving the adoption of m-learning: An empirical study. Computers and Education, 55(3), 1211-1219. https://doi.org/10.1016/j.compedu.2010.05.018

Lowenthal, J. N. (2010). Using mobile learning: Determinates impacting behavioral intention. American Journal of Distance Education, 24(4), 195-206. https://doi.org/10.1080/08923647.2010.519947

Maassen, G. H., \& Bakker, A. B. (2001). Suppressor variables in path models. Sociological Methods and Research, 30(2), 241-270. https://doi.org/10.1177/0049124101030002004 
The Adoption of Mobile Learning Systems

Masrek, M. N., \& Samadi, I. (2017). Determinants of mobile learning adoption in higher education setting. Asian Journal of Scientific Research, 10(2), 60-69. https://doi.org/10.3923/ajsr.2017.60.69

Moore, G. C., \& Benbasat, I. (1991). Development of an instrument to measure the perceptions of adopting an information technology innovation. Information Systems Research, 2(3), 192-222. https://doi.org/10.1287/isre.2.3.192

Motiwalla, L. F. (2007). Mobile learning: A framework and evaluation. Computers and Education, 49(3), 581-596. https://doi.org/10.1016/i.compedu.2005.10.011

Mtebe, J. S., \& Raisamo, R. (2014). Investigating students' behavioral intention to adopt and use mobile learning in higher education in East Africa. International Journal of Education and Development using Information and Communication Technology, 10(3), 4-20.

Neuman, W. L. (2006). Social research methods, qualitative and quantitative approaches (6th ed.). Boston: Allyn and Bacon.

Ozuorcun, N. C., \& Tabak, F. (2012). Is M-learning versus E-learning or are they supporting each other? Procedia - Social and Behavioral Sciences, 46, 299-305. https://doi.org/10.1016/j.sbspro.2012.05.110

Park, S. Y., Nam, M. W., \& Cha, S. B. (2012). University students' behavioral intention to use mobile learning: Evaluating the technology acceptance model. British Journal of Educational Technology, 43(4), 592-605. https://doi.org/10.1111/j.1467-8535.2011.01229.x

Rehman, M., Anjum, M., Askri, F., Kamran, M. A., \& Esichaikul, V. (2016). Mobile learning adoption framework: An empirical investigation from learners perspective. Journal of Quality and Technology Management, 12(1), 1-43.

Rosenberg, M. (2001). E-learning: Strategies for delivering knowledge in the digital age. New York: McGraw-Hill.

Sabah, N. M. (2016). Exploring students' awareness and perceptions: Influencing factors and individual differences driving m-learning adoption. Computers in Human Behavior, 65, 522-533. https://doi.org/10.1016/i.chb.2016.09.009

Sanchez-Prieto, J. C., Olmos-Miguelanez, S., \& Garcia-Penalvo, F. J. (2017). MLearning and pre-service teachers: An assessment of the behavioral intention using and expanded TAM model. Computers in Human Behavior, 72, 644-654. https://doi.org/10.1016/j.chb.2016.09.061

Schumacker, R. E., \& Lomax, R. G. (2016). A beginner's guide to structural equation modeling (4th ed.). New York: Routledge.

Shorfuzzaman, M., \& Alhussein, M. (2016). Modeling learner's readiness to adopt mobile learning: A perspective from a GCC higher education institution. Mobile Information Systems, 2016(3), 1-10. https://doi.org/10.1155/2016/6982824

Straub, D., Boudreau, M-C., \& Gefen, D. (2004). Validation guidelines for is positivist research. Communications of the Association of Information Systems, 13, 380-427.

Tan, G. W. H., Ooi, K. B., Leong, L. Y., \& Lin, B. (2014). Predicting the drivers of behavioral intention to use mobile learning: A hybrid SEM-neural networks approach. Computers in Human Behavior, 36, 198-213. https://doi.org/10.1016/i.chb.2014.03.052

Venkatesh, V., Morris, M. G., Davis, G. B., \& Davis, F. (2003). User acceptance of information technology: Toward a unified view. Management Information System Quarterly, 27(3), 425-478. https://doi.org/10.2307/30036540

Venkatesh, V., Thong, J. Y., \& Xu, X. (2012). Consumer acceptance and use of information technology: Extending the unified theory of acceptance and use of technology. Management Information System Quarterly, 36(1), 157-178.

Wang, Y. S., Wu, M. C., \& Wang, H. Y. (2009). Investigating the determinants and age and gender differences in the acceptance of mobile learning. British Journal of Educational Technology, 40(1), 92-118.

https://doi.org/10.1111/j.1467-8535.2007.00809.x 


\section{APPENDIX}

\section{Notated Questionnaire}

The questionnaire has been abbreviated and shows labels for variables and measurement scales.

\section{Section 1}

1 Your age (AGE):

2 Gender (SEX):

3 M-Learning Experience (EXP):

4 University (UNI):

5 Field of Study (FLD):

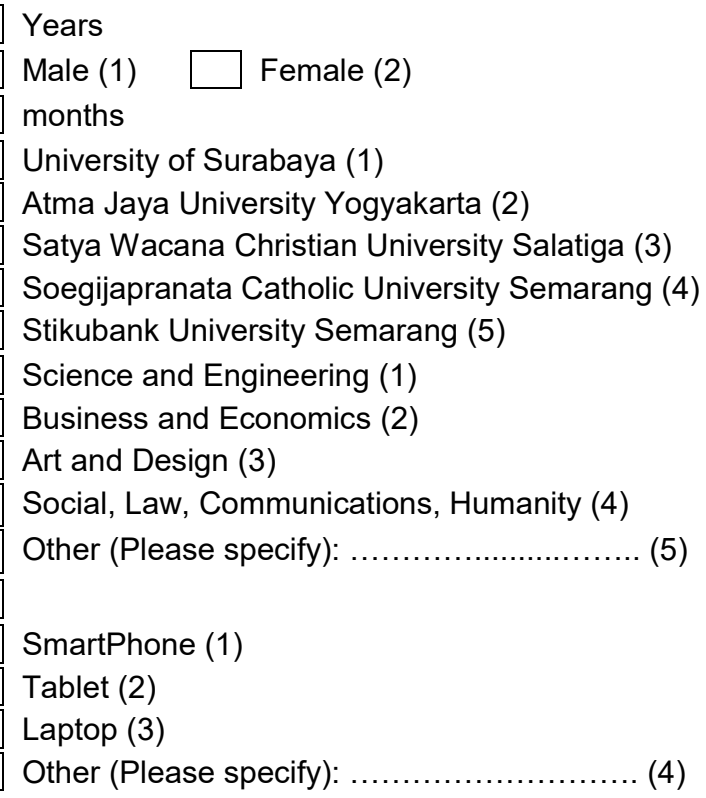

SmartPhone (1)

Tablet (2)

Laptop (3)

Other (Please specify):

6 You are at semester (SMT):

7 Main mobile device used for m-learning (DEV): 


\section{Section 2}

Each statement used the scale: Strongly Disagree(1), Disagree(2), Not Decided(3), Agree(4), Strongly Agree(5).

\begin{tabular}{|c|c|}
\hline \multicolumn{2}{|c|}{ Perceived Mobility (PM) } \\
\hline PM1 & It is convenient to access m-learning at anytime \\
\hline PM2 & It is convenient to access m-learning anywhere \\
\hline PM3 & Mobility makes it possible to get learning materials \\
\hline PM4 & Mobility is an outstanding advantage of m-learning \\
\hline \multicolumn{2}{|c|}{ Social Influence (SI) } \\
\hline SI1 & People who influence my behavior think that I should use m-learning \\
\hline SI2 & People who are important to me think that I should use m-learning \\
\hline $\mathrm{SI}$ & The seniors at my university have been helpful in my use of m-learning \\
\hline SI4 & In general, my university has supported my use of m-learning \\
\hline \multicolumn{2}{|r|}{ Self-Efficacy (SE) } \\
\hline SE1 & I have the necessary skills to use m-learning \\
\hline SE2 & I am a skillful user of menus or software for m-learning with mobile devices \\
\hline SE3 & I have confidence in using computer and mobile devices for m-learning \\
\hline SE4 & I understand the terms used for computer and mobile devices used for m-learning \\
\hline \multicolumn{2}{|r|}{ Perceived Innovativeness (PI) } \\
\hline $\mathrm{PI}$ & I like to experiment with new information technologies \\
\hline $\mathrm{PI} 2$ & When I hear about a new information technology I look forward to examining it \\
\hline $\mathrm{PI} 3$ & Among my colleagues, I am usually the first to try out a new innovation in technology \\
\hline $\mathrm{Pl} 4$ & New technologies are interesting to me \\
\hline \multicolumn{2}{|c|}{ Facilitating Conditions (FC) } \\
\hline FC1 & I have the resources necessary to use m-learning \\
\hline $\mathrm{FC} 2$ & I have the knowledge necessary to use m-learning \\
\hline FC3 & M-learning applications are similar to other systems I use with mobile devices \\
\hline FC4 & Help is available when I get problem in using m-learning applications \\
\hline \multicolumn{2}{|r|}{ Learning Autonomy (LA) } \\
\hline LA1 & When it comes to learning and studying, I am a self-directed person \\
\hline LA2 & In my studies, I am self-disciplined and find it easy to set aside reading and home-work time \\
\hline LA3 & I am able to manage my study time effectively and easily complete assignments on time \\
\hline LA4 & In my studies, I set goals and have a high degree of initiative \\
\hline \multicolumn{2}{|r|}{ Perceived Enjoyment (PE) } \\
\hline PE1 & M-learning makes me feel good \\
\hline PE2 & M-learning is interesting \\
\hline PE3 & I have fun using m-learning \\
\hline PE4 & Using m-learning is enjoyable \\
\hline \multicolumn{2}{|c|}{ Perceived Usefulness (PU) } \\
\hline PU1 & I find m-learning useful in my learning \\
\hline PU2 & Using m-learning enables me to accomplish learning activities more quickly \\
\hline PU3 & Using m-learning increases my learning productivity \\
\hline PU4 & If I use m-learning then I increase my chances of getting a better grade \\
\hline \multicolumn{2}{|r|}{ Perceived Ease of Use (PEU) } \\
\hline PEU1 & My interaction with m-learning is clear and understandable \\
\hline PEU2 & It is easy for me to become skillful at using m-learning \\
\hline PEU3 & I find m-learning easy to use \\
\hline PEU4 & Using m-learning is easy for me \\
\hline \multicolumn{2}{|r|}{ Behavioral Intention (BI) } \\
\hline $\mathrm{Bl1}$ & If $\mathrm{m}$-learning is available to me in the future then I would like to use it \\
\hline $\mathrm{BI} 2$ & Whenever I have the opportunity I will use m-learning \\
\hline $\mathrm{BI} 3$ & If possible then I plan to use m-learning in the future \\
\hline $\mathrm{B} 14$ & I would like to use m-learning again in the future \\
\hline
\end{tabular}


Table A1: Recommended fit statistics and interpretation (Kline, 2016)

\begin{tabular}{|l|l|}
\hline Model Fit Statistics & Interpretations \\
\hline Model Chi-Square $x^{2}$ & Small values of $\mathrm{X} 2$ with $p>0.05$ indicate at least a reasonable fit. \\
\hline $\begin{array}{l}\mathrm{X}^{2} / \mathrm{df}(\text { Normed Chi-square, NC) } \\
\text { where df is the degrees of freedom }\end{array}$ & $\begin{array}{l}\text { Values of } 1<\mathrm{NC}<5 \text { are considered to indicate at least a reasonable } \\
\text { model fit. }\end{array}$ \\
\hline RMR (Root Mean Square Residual) & $\begin{array}{l}\text { RMR values close to } 0 \text { indicate a good model fit. The fit gets worse as } \\
\text { the value of RMR increases. }\end{array}$ \\
\hline $\begin{array}{l}\text { GFI (Goodness of Fit Index) } \\
\text { AGFI (Adjusted GFI) }\end{array}$ & $\begin{array}{l}\text { GFI } 1 \text { means a perfect fit, GFI }>0.9 \text { means a good fit, GFI }=0 \text { indi- } \\
\text { cates a poor fit. AGFI corrects GFI downward based on model com- } \\
\text { plexity. }\end{array}$ \\
\hline $\begin{array}{l}\text { NFI (Normed Fit Index) } \\
\text { IFI (Incremental Fit Index) } \\
\text { CFI (Comparative Fit Index) }\end{array}$ & NFI, IFI, CFI should have values $>0.9$ to indicate a good model fit. \\
\hline $\begin{array}{l}\text { RMSEA (Root Mean Square Error of } \\
\text { Approximation) }\end{array}$ & $\begin{array}{l}\text { RMSEA less than or equal to } 0.05 \text { means a close fit; between } 0.05 \\
\text { and } 0.08 \text { means a reasonable fit, } 0.1 \text { or more indicates a poor fit. }\end{array}$ \\
\hline
\end{tabular}

Table A2: Validity and reliability analyses

\begin{tabular}{|c|c|c|c|c|c|c|c|c|c|c|c|}
\hline \multirow[b]{2}{*}{ 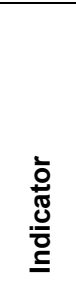 } & \multicolumn{10}{|c|}{ Latent Variable } & \multirow{2}{*}{$\begin{array}{c}\text { Cronbac } \\
\text { h Alpha } \\
\text { Coeffi- } \\
\text { cient }\end{array}$} \\
\hline & $\begin{array}{l}\text { Learn- } \\
\text { ing } \\
\text { Auton- } \\
\text { omy }\end{array}$ & $\begin{array}{l}\text { Per- } \\
\text { sonal } \\
\text { Innova- } \\
\text { tive } \\
\text { ness } \\
\end{array}$ & $\begin{array}{l}\text { Per- } \\
\text { ceived } \\
\text { Enjoy- } \\
\text { ment }\end{array}$ & $\begin{array}{l}\text { Behav- } \\
\text { ioral } \\
\text { Inten- } \\
\text { tion }\end{array}$ & $\begin{array}{l}\text { Per- } \\
\text { ceived } \\
\text { Ease } \\
\text { of Use }\end{array}$ & $\begin{array}{l}\text { Self- } \\
\text { Effi- } \\
\text { cacy }\end{array}$ & $\begin{array}{l}\text { Social } \\
\text { Influ- } \\
\text { ence }\end{array}$ & $\begin{array}{l}\text { Per- } \\
\text { ceived } \\
\text { Useful- } \\
\text { ness }\end{array}$ & $\begin{array}{l}\text { Per- } \\
\text { ceived } \\
\text { Mobili- } \\
\text { ty }\end{array}$ & $\begin{array}{l}\text { Facilitat- } \\
\text { ing Con- } \\
\text { dition }\end{array}$ & \\
\hline LA2 & .865 & .088 & -.007 & .067 & .066 & .049 & .033 & .144 & -.026 & .060 & .891 \\
\hline LA3 & .864 & .108 & .015 & .045 & .105 & .074 & -.035 & .078 & .026 & .027 & (Good) \\
\hline LA4 & .834 & 110 & .087 & .074 & .044 & .005 & .028 & .086 & .038 & .029 & \\
\hline LA1 & .831 & .106 & .072 & .060 & .046 & .035 & .042 & .021 & .031 & .085 & \\
\hline $\mathrm{PI} 2$ & .143 & .847 & .067 & .083 & .058 & .054 & .036 & .029 & -.051 & .053 & .884 \\
\hline PI4 & .132 & .842 & 109 & .055 & .096 & .082 & .086 & .047 & .050 & .059 & (Good) \\
\hline PI3 & .093 & .838 & .012 & .100 & .061 & .146 & .022 & .094 & .002 & .087 & \\
\hline PI1 & .063 & .794 & .066 & .064 & .087 & .216 & .025 & .011 & .053 & .081 & \\
\hline PE3 & .064 & .105 & .787 & .175 & .164 & .084 & .143 & .223 & .157 & .084 & .895 \\
\hline PE4 & .020 & .037 & .786 & .180 & .172 & .094 & .089 & .262 & .171 & .083 & (Good) \\
\hline PE2 & .013 & .132 & .780 & 186 & .083 & .086 & .082 & .171 & .117 & .164 & \\
\hline PE1 & .113 & .032 & .716 & .103 & .083 & .083 & .141 & .282 & .205 & .129 & \\
\hline $\mathrm{BI} 3$ & .094 & .039 & .149 & .817 & .151 & .093 & .111 & .112 & .123 & .145 & .887 \\
\hline BI4 & .095 & .095 & .165 & .796 & .144 & .113 & .116 & .160 & .126 & .126 & (Good) \\
\hline $\mathrm{BI} 2$ & .086 & .116 & .147 & .760 & .135 & .058 & .117 & .211 & .129 & .060 & \\
\hline $\mathrm{BI} 1$ & .016 & .102 & .148 & .750 & .135 & .183 & .037 & .218 & .088 & .146 & \\
\hline PEU3 & .042 & .022 & .095 & .117 & .830 & .091 & .068 & .137 & .147 & .177 & .882 \\
\hline PEU4 & .097 & .132 & .103 & .161 & .795 & .178 & .034 & .105 & .074 & .168 & (Good) \\
\hline PEU2 & .069 & .134 & .131 & .111 & .776 & .199 & .062 & 140 & .115 & 199 & \\
\hline PEU1 & .120 & .072 & .161 & .204 & .662 & .137 & .091 & .223 & .138 & .155 & \\
\hline SE2 & .020 & .100 & .077 & .097 & .165 & .812 & .054 & .051 & .124 & .189 & .876 \\
\hline SE4 & .073 & .225 & .037 & .089 & .205 & .777 & .084 & .006 & .081 & .170 & (Good) \\
\hline SE1 & .033 & .075 & .092 & .131 & .060 & .760 & .111 & .056 & .187 & .258 & \\
\hline SE3 & .071 & .184 & .122 & .117 & .151 & .724 & .106 & .125 & .077 & .229 & \\
\hline SI1 & .020 & .080 & .031 & .084 & .061 & .068 & .835 & .104 & .115 & .047 & .851 \\
\hline SI4 & -.013 & -.015 & .092 & .066 & .031 & .083 & .819 & .074 & .095 & .069 & (Good) \\
\hline $\mathrm{SI} 2$ & .013 & .101 & .062 & .102 & .069 & .047 & .816 & .148 & .064 & .040 & \\
\hline $\mathrm{SI} 3$ & .050 & .003 & .177 & .070 & .054 & .090 & .744 & -.001 & .077 & .099 & \\
\hline PU2 & .080 & .028 & .187 & .154 & .096 & .043 & .088 & .832 & .139 & .095 & .876 \\
\hline PU3 & .134 & .031 & .240 & .215 & .187 & .070 & .113 & .758 & 119 & .070 & (Good) \\
\hline PU1 & .081 & .040 & .296 & .165 & .132 & .059 & .113 & .677 & .205 & .198 & \\
\hline PU4 & .134 & .126 & .234 & .227 & .224 & .067 & .091 & .662 & .186 & .068 & \\
\hline PM1 & .053 & .014 & .146 & .106 & .032 & .084 & .021 & .189 & .797 & .156 & .780 \\
\hline PM2 & .050 & -.012 & .126 & .106 & .027 & .079 & .039 & .223 & .782 & .135 & (Accepta- \\
\hline PM3 & -.029 & .025 & .075 & .115 & .164 & .066 & .164 & .139 & .669 & .003 & ble) \\
\hline PM4 & -.007 & .013 & .185 & .074 & .198 & .201 & .150 & -.041 & .631 & .026 & \\
\hline
\end{tabular}




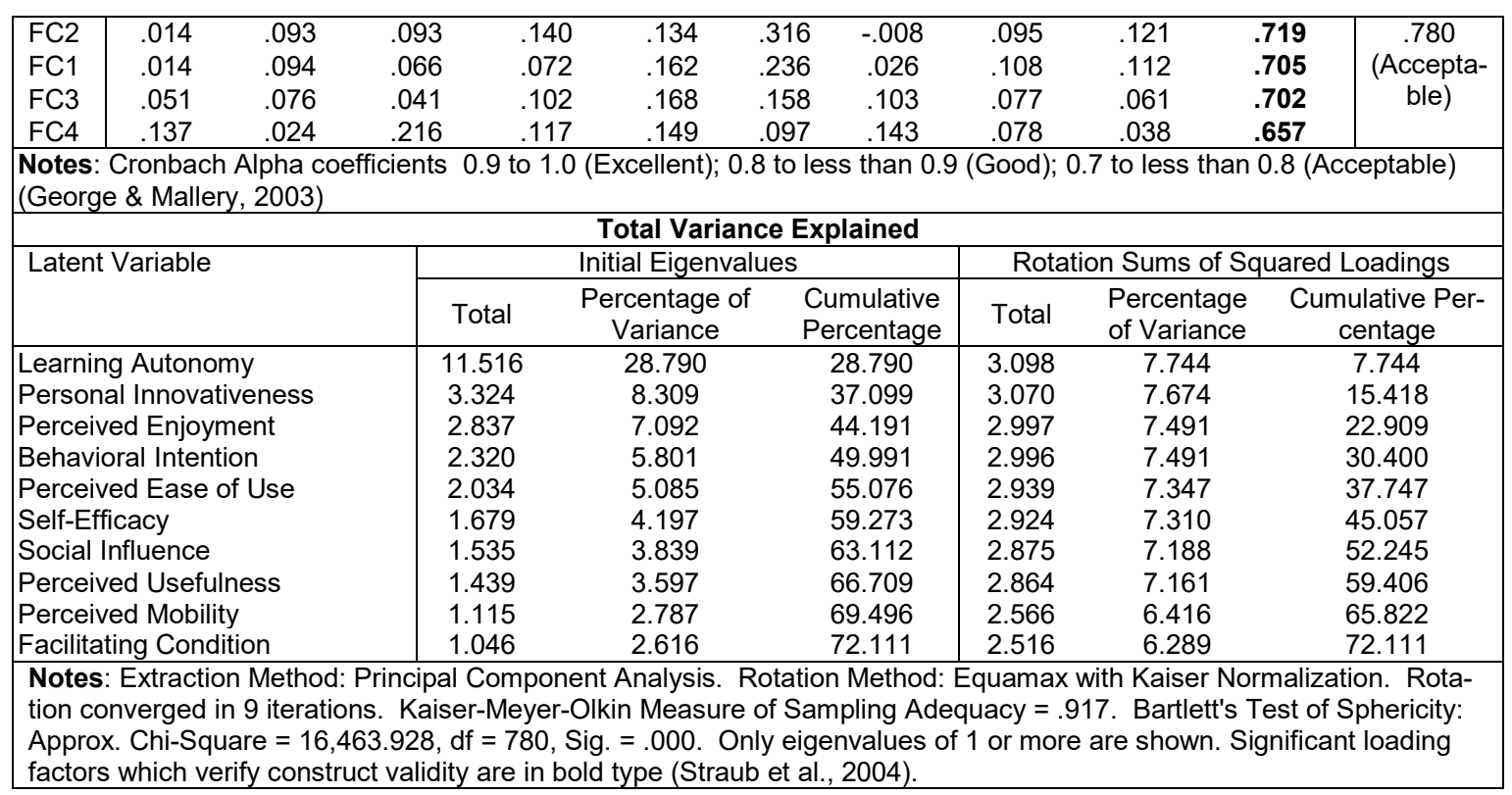

\section{BIOGRAPHY}

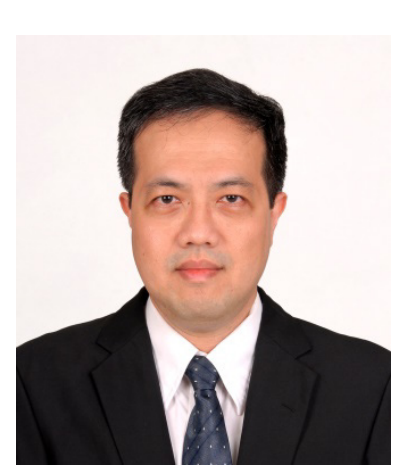

Edwin Pramana is a PhD candidate at Vincent Mary School of Science and Technology, Assumption University of Thailand. He holds a Bachelor of Computer Science degree from Sekolah Tinggi Teknik SurabayaIndonesia and a Master of Information Technology degree from Queensland University of Technology-Australia. He is a lecturer at the department of Computer Science, Sekolah Tinggi Teknik Surabaya, Indonesia. His research interests are Information Technology adoption in Organizations and Educational Technology. 